\title{
Early Tournaisian ammonoids from Timimoun (Gourara, Algeria)
}

\author{
Volker Ebbighausen ${ }^{1}$, Jürgen Bockwinkel ${ }^{2}$, Dieter Korn $^{3}$ \& Dieter Weyer ${ }^{4}$
}

With 18 figures

\begin{abstract}
A small ammonoid fauna, of probable middle Early Tournaisian age, is described from the Gara el Kahla near Timimoun, Gourara, Algerian Sahara. The following taxa are described: Acutimitoceras algeriense n. sp., Acutimitoceras sinulobatum $\mathrm{n}$. sp., Acutimitoceras sp. A, Hasselbachia gourara n. sp., Gattendorfia jacquelinae n. sp., Gattendorfia cf. crassa Schmidt, 1924, Kahlacanites n. gen., Kahlacanites meyendorffi n. sp., Kahlacanites mariae n. sp., and Kahlacanites timimounensis n. sp.
\end{abstract}

Key words: Ammonoidea, Tournaisian, Carboniferous, Algeria, biostratigraphy

\section{Zusammenfassung}

Eine kleine Ammonoideenfauna mit wahrscheinlich mittlerem Untertournai-Alter von der Gara el Kahla bei Timimoun (Gourara, Algerische Sahara) wird untersucht. Die folgenden Taxa warden beschrieben: Acutimitoceras algeriense n. sp., Acutimitoceras sinulobatum n. sp., Acutimitoceras sp. A, Hasselbachia gourara n. sp., Gattendorfia jacquelinae n. sp., Gattendorfia cf. crassa Schmidt, 1924, Kahlacanites n. gen., Kahlacanites meyendorffi n. sp., Kahlacanites mariae n. sp. und Kahlacanites timimounensis $\mathrm{n}$. sp.

Schlüsselwörter: Ammonoidea, Tourhaisium, Karbon, Algerien, Biostatigraphie

\section{Introduction}

The Hangenberg Event is one of the major crises in the evolution of the ammonoids and resulted in a near-complete extinction of the entire clade (e.g., Korn 1993). Only two groups of ammonoids are known from both sides of the Hangenberg Black Shale, the prionoceratid goniatites and the cymaclymeniid clymeniids, of which the latter became extinct without descendants soon after the Hangenberg Event. It can be regarded as a failed survivor and falls in the Dead Clade Walking concept (Jablonski 2002).

Diverse ammonoid assemblages from the first time intervals after the Hangenberg Event are known from only a few places in the world, and hence every new record is important to document the Late Devonian decline of the group and their earliest Carboniferous recovery and radiation.
This is particularly the case for occurrences far away from the classical Central European localities in the Rhenish Mountains (e.g., Vöhringer 1960), Thuringia (e.g., Weyer 1977), Franconia (e.g., Schindewolf 1923), Silesia (e.g., Weyer 1965), and the Carnic Alps (e.g., Korn 1992). Apart from these regions, rich Early Tournaisian ammonoid assemblages are only known from Guizhou (e.g., Ruan 1981) and Karaganda (Librovitch 1940).

Early Tournaisian ammonoids from North Africa were mentioned and figured several times in the literature. Hollard $(1956,1958)$ listed occurrences of species of Gattendorfia and "Imitoceras gurichi" from the Ma'der and the Drâa Valley of Morocco. Conrad et al. (1970) reported Gattendorfia from the Saoura Valley near Béni Abbès in Algeria.

The locality near the Gara el Kahla southwest of Timimoun was discovered by Meyendorff

\footnotetext{
1 Engstenberger Höhe 12, D-51519 Odenthal, Germany. E-mail: volker@vxr.de

2 Dechant-Fein-Straße 22, D-51375 Leverkusen, Germany. E-mail: jbockwinkel@t-online.de

3 Museum für Naturkunde der Humboldt-Universität zu Berlin, Invalidenstraße 43, D-10115 Berlin, Germany. E-mail: dieter.korn@museum.hu-berlin.de

4 Löwestraße 15, D-10249 Berlin, Germany. E-mail: dieter.weyer@t-online.de

Received February 2004, accepted May 2004
} 
(1939), who first recorded Algerian Early Tournaisian ammonoids and listed "Gattendorfia cf. crassa", "Gattendorfia sp.", and "Aganides sp.". Later, Conrad (1984) figured specimens of "Gattendorfia gr. crassa" from this occurrence.

Here, we describe a small assemblage with Gattendorfia from the Gara el Kahla. It consists of nine species and is therefore the richest African ammonoid fauna yet reported from this time interval.

\section{Locality and material}

During a re-visit of Meyendorff's and Conrad's Gattendorfia locality by the first three authors in November, 2003, the assemblage described in the following account was collected at two neighbouring places. Further specimens were made available by Marie Legrand-Blain (Bordeaux), which were collected by her in 1968.

All the material comes from the immediate vicinity of the table mountain Gara el Kahla, $35 \mathrm{~km}$ southwest of Timimoun, mapsheet $1: 100000 \mathrm{NH}-30$-XII Charouin, geographic co-ordinates $\mathrm{N} 29^{\circ} 05,675^{\prime}$, W $00^{\circ} 02,370^{\prime}$ (Fig. 1). It was collected at two localities from a $2-3$ metre thick interval in the middle portion of an approximately 50 metres thick claystone package within the Grès supérieurs de Kahla (Conrad 1984: 131, fig. 21). Therefore mixing of the surface-collected assemblage can be ruled out.

The entire assemblage is preserved as limonitic steinkerns which weather from dark-grey claystones that contain scattered sideritic nodules and fine-grained thin sandstone horizons. All the specimens are small, and the largest phragmocone has a diameter of only $20 \mathrm{~mm}$. This does not mean. however, that only juveniles are present. Many of the larger specimens display characteristic adult aspects. such as septal crowding. Most of the specimens are strongly corroded, distorted, or fragmentary. However, 355 clearly identifiable ammonoid specimens out of a total of approximately 800 specimens are available. The following species are represented:

locality A:

Acutimitoceras algeriense $\mathbf{n} . \mathbf{s p}$.

Acutimitoceras sinulobatum n. sp.

Acutimitoceras sp. A

Acutimitoceras sp. indet.

Hasselbachia gourara n. sp.

Gattendorfia jacquelinae n. sp.

Gattendorfia cf. crassa Schmidt, 1924

Kahlacanites meyendorffi $\mathrm{n}$. sp.

Kahlacanites mariae n. $\mathrm{sp}$.

Kahlacanites timimounensis n. sp.

36 specimens

40 specimens

59 specimens

380 specimens

12 specimens

152 specimens

1 specimen

3 specimens

10 specimens

11 specimens

locality B:

Acutimitoceras algeriense $\mathrm{n}$. $\mathrm{sp}$.

Acutimitoceras sinulobatum n. sp.

Acutimitoceras sp. indet.

Hasselbachia gourara $\mathrm{n}$. sp.

Gattendorfia jacquelinae n. sp.

Kahlacanites mariae n. sp.

3 specimens

4 specimens

60 specimens

1 specimen

14 specimens

2 specimens

4 specimens

12 specimens

3 specimens
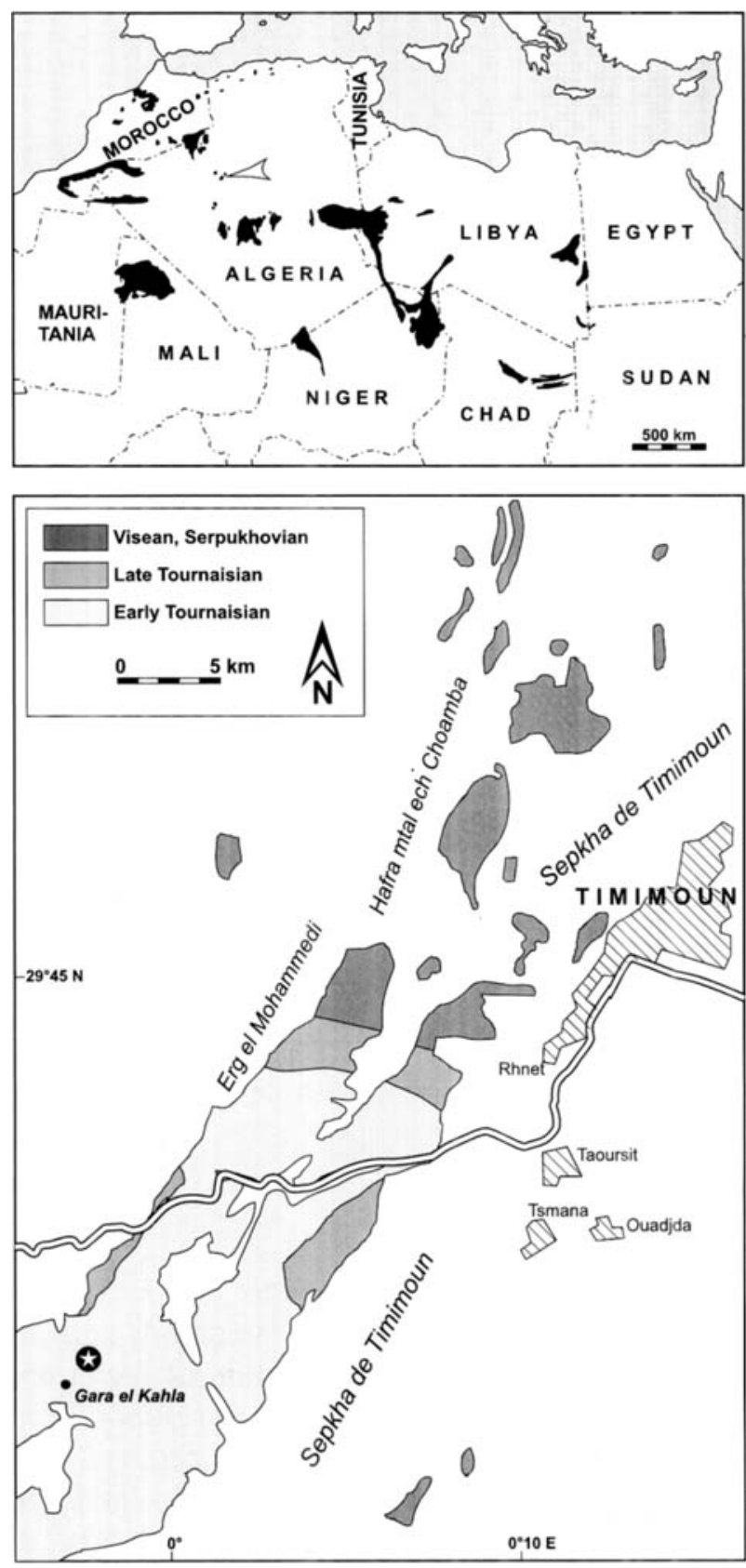

Fig. 1. Geographic position of the Gara el Kahla locality. A Outcropping Carboniferous rocks (black) in North Africa with indication of the area of Timimoun. B. Geological map of the area southwest of Timimoun showing the position of the ammonoid locality (indicated by asterisk) near the Gara el Kahla.

spiriferids (such as ambocoeliids), of which the latter are especially abundant. Further associated fauna consists of few orthocone cephalopods, gastropods (Naticopsis? and Mourlonia?), bellerophontids (Retispira?/Euphemites?), crinoids, and rare rugose corals (mentioned by Conrad 1984: 131; "faune à Cyathaxonia"; Rotiphyllum?)

\section{Stratigraphic age of the fauna}

Because of its exclusive composition, the Gara el Kahla ammonoid assemblage is not indicative for
Associated fauna includes particularly brachiopods, of which tids, orthids, rhynchonellids, as well as ribbed and smooth 


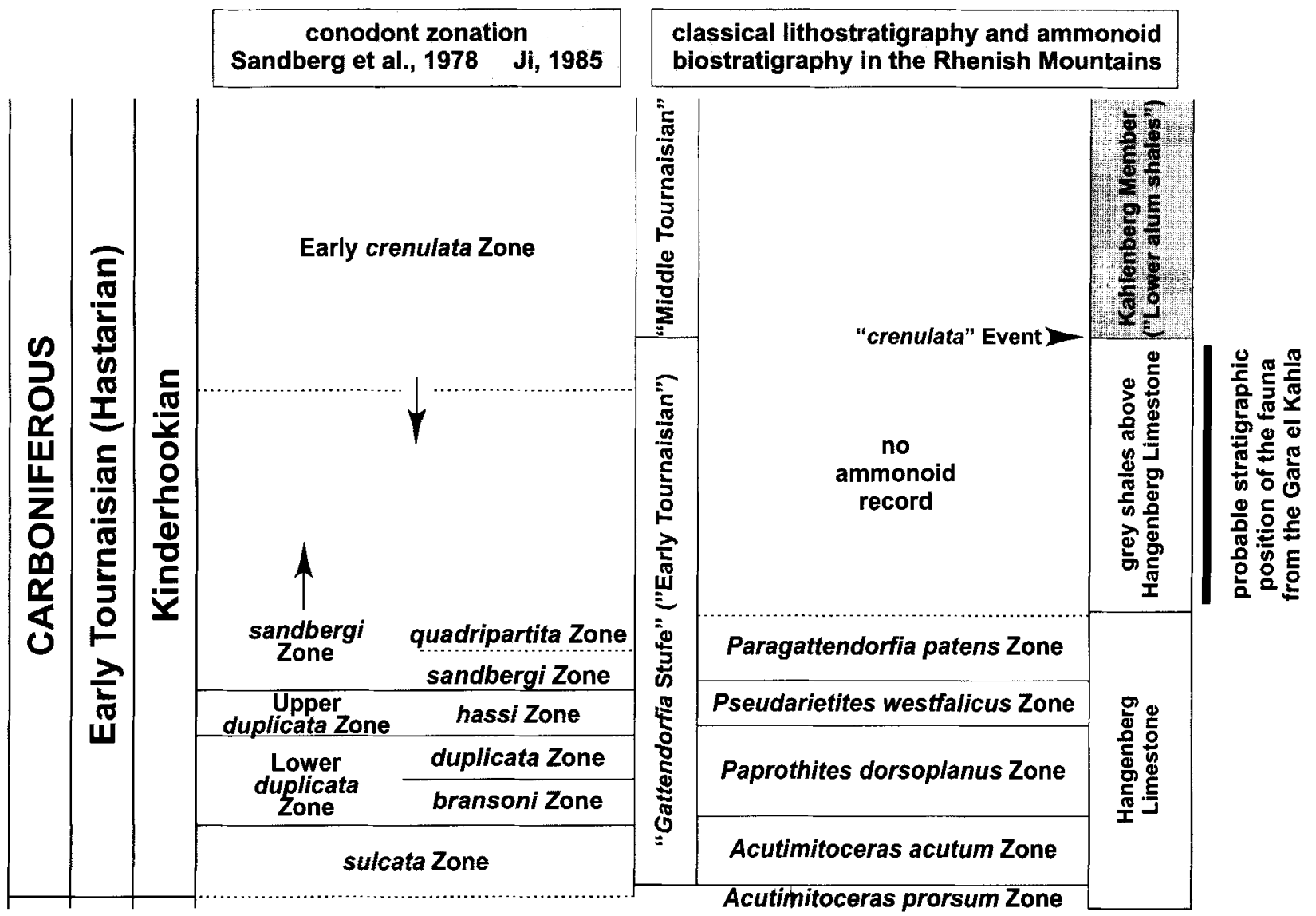

Fig. 2. Stratigraphic subdivision of the Early Tournaisian and probable position of the fauna from the Gara el Kahla.

a certain position within the ammonoid succession known from the classical outcrop in the railway cutting of Ober-Rödinghausen, Rhenish Mountains, Germany (Vöhringer 1960).

Several of the species from the Gara el Kahla represent independent evolutionary lineages possessing pouched external lobes which are very rare in faunas of typical Gattendorfia Stufe age, thus a Paragattendorfia patens Zone or even younger age is most likely. Korn \& Weyer (2003) noted that there exists a hitherto neglected time interval between the Hangenberg Limestone and the base of the Lower Alum Shale (global "crenulata" Event; Kahlenberg Member, see Korn 2003) in sections of the Rhenish Mountains, possibly represented by grey shales varying in thickness from few centimetres to approximately 4.40 metres. This horizon has so far yielded no ammonoids, and it is perhaps somewhat speculative to presume Gattendorfia faunas there; nevertheless it corresponds to the estimated level of the peculiar fauna from Karaganda (Kazakhstan) described by Librovitch (1940). The same hiatus in chronostratigraphic knowledge was already reported by Bartzsch \& Weyer (1982: 30, fig. 2) from the Saalfeld section in Thuringia (upper
4,36 $\mathrm{m}$ of the 8,44 $\mathrm{m}$ thick Pfaffenberg Member sensu Bartzsch et al. 1999: 179). This unit did not yield ammonoids, but contained other faunal elements including conodonts. Thus either an extension of the Paragattendorfia patens Zone or, more probably, several so far unnamed ammonoid zones occur in this still nearly unexplored global time interval (Fig. 2). Further investigations, however, will surely solve the problem of the age of the ammonoid assemblage from the Gara el Kahla.

\section{Palaeontological descriptions of the ammonoids}

[Abbreviations used in the text are: $\mathrm{dm}-$ conch diameter, ww - whorl width, wh - whorl height, uw - umbilical width, ah - apertural height, WER - whorl expansion rate, calculated [dm/ $(\mathrm{dm}-\mathrm{ah})]^{2}$, IZR - imprint zone rate, calculated (wh-ah)/wh (see Korn \& Weyer 2003). Described and illustrated specimens are housed in the collection of the Museum für Naturkunde der Humboldt-Universität $\mathrm{zu}$ Berlin, with the catalogue numbers MB.C.5462 to MB.C.5474.] 
Family Prionoceratidae Hyatt, 1884

Subfamily Acutimitoceratinae Korn, 1994

\section{Acutimitoceras Librovitch, 1957}

Type species: Imitoceras acutum Schindewolf. 1923

\section{Acutimitoceras algeriense $\mathbf{n} . \mathbf{s p}$.}

Derivation of name: After Algeria, where the material was collected.

Holotype: Specimen MB.C.5463.1 (coll. Legrand-Blain 1968); figured here in Fig. 3A, B.

Type locality and horizon: Dry plain immediately northeast of the Gara el Kahla $35 \mathrm{~km}$ southwest of Timimoun, Gourara, Algeria; clay- stone horizon in the Grès supérieurs de Kahla, probably middle part of the Early Tournaisian.

Material: 43 specimens between 7.5 and $20 \mathrm{~mm}$ conch diameter.

Diagnosis: Species of Acutimitoceras with discoidal conch. Inner whorls up to $5 \mathrm{~mm}$ diameter with open umbilicus (uw/dm 0.15), umbilicus closed in later stages. Aperture high, whorl expansion rate higher than 2.10 in stages larger than $5 \mathrm{~mm}$ diameter. Steinkern with slightly biconvex constrictions. Suture line with narrow, lanceolate and slightly pouched external lobe and V-shaped adventive lobe.

Description: Intraspecific variation is rather low in Acutimitoceras algeriense, as can be seen
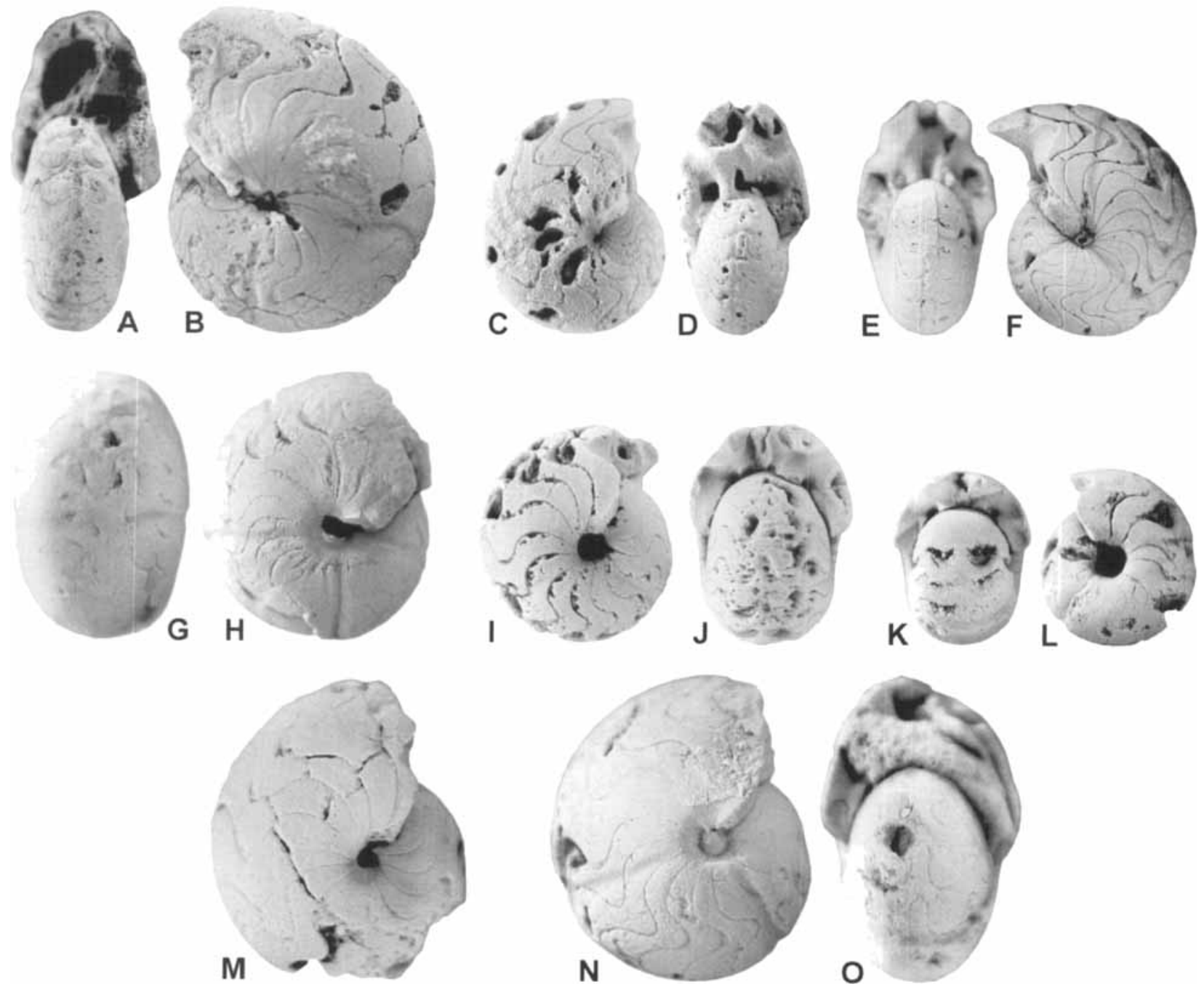

Fig. 3. Species of Acutimitoceras from the Grès supérieurs de Kahla of the Gara el Kahla, all coll. Ebbighausen, Bockwinkel, and Korn 2003. except for fig. A. B (coll. Legrand-Blain 1968). A. B. Acutimitoceras algeriense n. sp., MB.C.5463.1, dorsal and lateral views, $\times 2.5$. C, D. Acutimitoceras algeriense n. sp.. MB.C.5464.7, lateral and dorsal views, $\times 4$. E, F. Acutimitoceras algeriense n. sp., MB.C.5464.11, dorsal and lateral views, $\times$ 4. G, H. Acutimitoceras sinulobatum n. sp., MB.C.5465.1, ventral and lateral views, $\times 3$. I, J. Acutimitoceras sinulobatum n. sp., MB.C.5465.5, lateral and dorsal views, $\times 3$. K. L. Acutimitoceras sinulobatum n. sp., MB.C.5475.6. dorsal and lateral views, $\times 3$. M. Acutimitoceras sp. A, MB.C.5476.2, lateral view, $\times 3 . \mathbf{N}, \mathbf{O}$. Acutimitoceras sp. A. MB.C.5466.5. lateral and dorsal views, $\times 4$. 

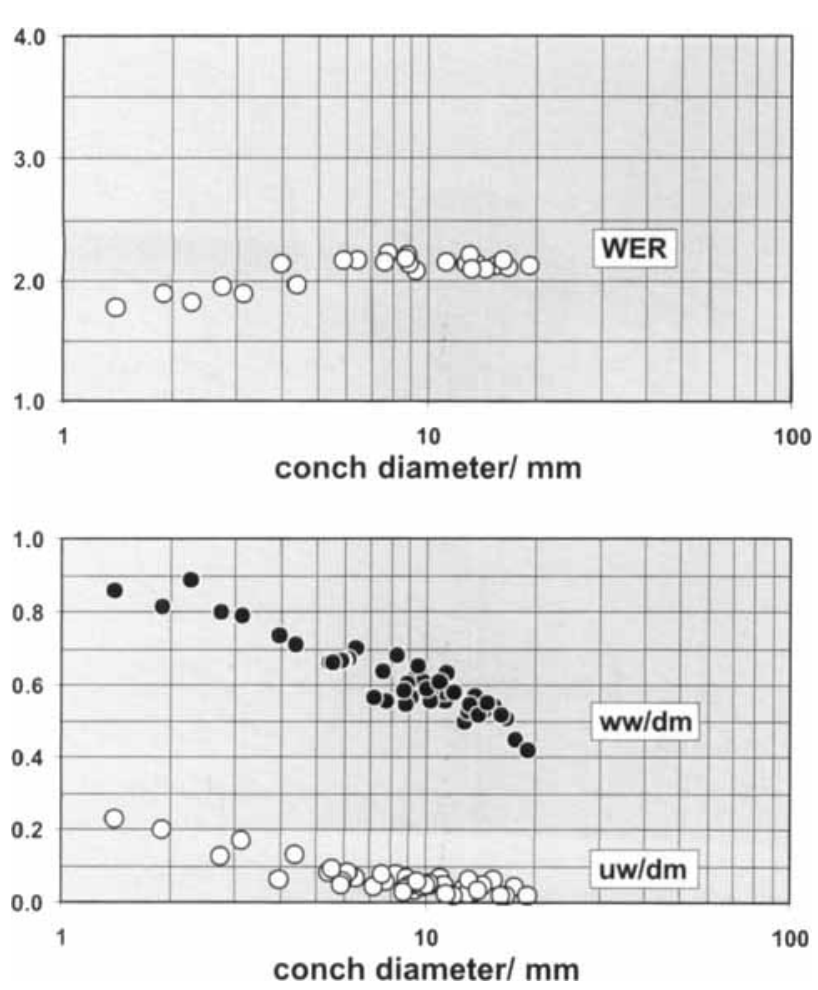

Fig. 4. Bivariate plot of whorl expansion rate (WER) as well as whorl width/conch diameter and umbilical width/conch diameter ratios of Acutimitoceras algeriense n. sp.

in Fig. 4. The bivariate plot of the whorl expansion rate demonstrates that there is an ontogenetic change from low apertures in small juveniles (WER 1.8) towards higher apertures (WER higher than 2.05) in stages between 5 and $20 \mathrm{~mm}$ conch diameter, where no further ontogenetic development can be observed. A similar picture is offered by the plot of the relative umbilical width. After a slightly opened early ontogenetic stage, there is an almost complete closure of the umbilicus visible in stages larger than $5 \mathrm{~mm}$ conch diameter. Adults of more than $15 \mathrm{~mm}$ conch diameter posses a punctiform umbilicus. Early stages have a thickly pachyconic conch (ww/dm 0.80 at $3 \mathrm{~mm} \mathrm{dm}$ ); a ratio of 0.60 is reached at $10 \mathrm{~mm} \mathrm{dm}$, and a ratio of 0.40 can be seen in the largest specimen at $20 \mathrm{~mm}$ conch diameter. In this character, a wider variability of specimens between 8 and $12 \mathrm{~mm}$ diameter is visible in the bivariate plot.

In the sectioned paratype MB.C.5464.1 (Fig. 5A), the ontogenetic development between 2 and $13.5 \mathrm{~mm}$ conch diameter can be observed. Within this range, a decrease in relative thickness from 0.89 to 0.56 is visible, with a tendency from crescent-shaped juvenile whorls to adult whorls with high aperture. The specimen possesses a characteristic funnel-shaped umbilicus, and the umbilical wall is oblique, especially at the larger diameter. Closure of the umbilicus starts early in ontogeny; already at $3 \mathrm{~mm}$ conch diameter, the umbilicus is closed to a value of 0.17 of the conch diameter. At $9 \mathrm{~mm}$ diameter, the umbilicus is punctiform (uw/dm 0.03). The aperture is rather high, and the whorl expansion rate exceeds 2.00 at only $5 \mathrm{~mm}$ conch diameter. Between 6 and $14 \mathrm{~mm} \mathrm{dm}$, it ranges between 2.09 and 2.16 .

Holotype MB.C.5463.1 is a fully septate phragmocone of $19 \mathrm{~mm}$ diameter with 17 septa; the conch is discoidal (ww/dm 0.42) and thickest near the funnel-shaped, nearly closed umbilicus. The flanks converge towards the broadly rounded venter, and the aperture is high (WER 2.12). Three weak constrictions are visible on the last volution; they begin beyond the umbilical margin and run with a barely visible, very shallow lateral sinus, a very low ventrolateral projection, and a more pronounced, widely semicircular ventral sinus. Otherwise, the steinkern is almost completely smooth.

The smaller paratype MB.C.5464.7 has a similar pachyconic conch (ww/dm 0.61 ) at $9 \mathrm{~mm}$ diameter. This specimen has a rounded umbilical margin, and uniformly rounded flanks and venter. The aperture is high as in the holotype, with a whorl expansion rate of 2.14. Three almost linear steinkern constrictions are arranged in distances of approximately $120^{\circ}$. Major differences between the specimens can be seen in the presence of constrictions; the two specimens MB.C.5464.2 (18 $\mathrm{mm} \mathrm{dm})$ and MB.C.5464.11 $(9 \mathrm{~mm} \mathrm{dm})$ do not show any constrictions.

The suture lines of two specimens, paratype MB.C.5463.1 (at $14 \mathrm{~mm} \mathrm{dm}$ ) and paratype MB.C.5464.7 (at $8.8 \mathrm{~mm} \mathrm{dm}$ ) show similar outlines (Fig. 5F, G). Both show a narrow lanceolate, slightly pouched external lobe, which is deeper than the adventive lobe in the larger holotype but shorter in the smaller paratype. The ventrolateral saddle is wide and broadly rounded in both; it is asymmetric and appears to be ventrally inclined. Both specimens possess a rather wide, almost symmetric and acute adventive lobe with slightly sinuous flanks.

Discussion: Acutimitoceras algeriense is easily distinguishable from all other species of the genus which occur in the Hangenberg Limestone of Germany (Vöhringer 1960, Korn 1994) by its comparatively high whorl expansion rate of more than 2.10 that leads to a high aperture even in in juvenile stages (1.70 to 1.90 in other species of Acutimitoceras). A further criterion for separation is the slightly pouched external 


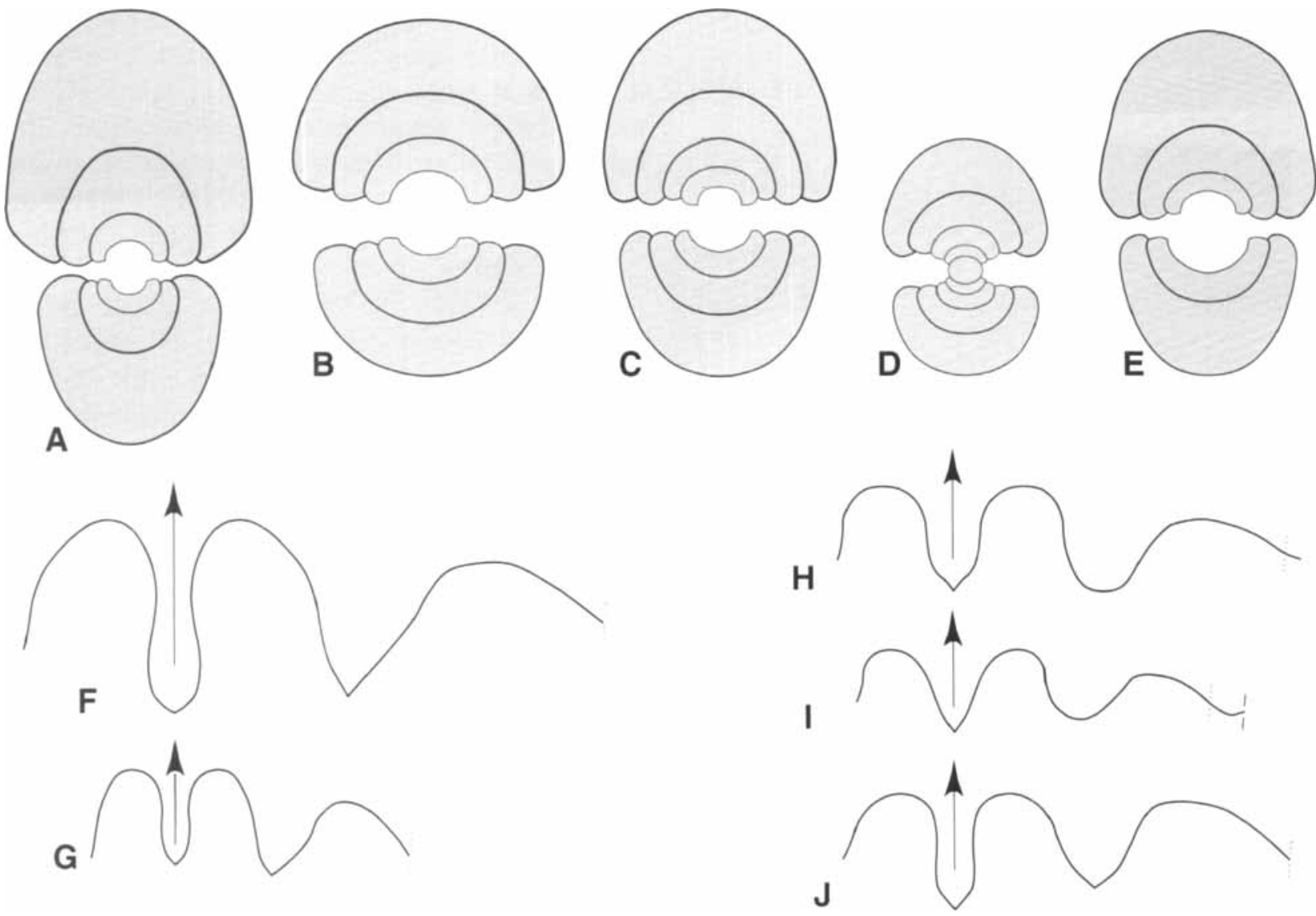

Fig. 5. Cross sections $(\mathrm{A}-\mathrm{E} ; \times 4)$ and suture lines $(\mathrm{F}-\mathrm{J} ; \times 6)$ of species of Acutimitoceras from the Grès supérieurs de Kahla of the Gara el Kahla. A. Actutimitoceras algeriense n. sp. MB.C.5464.1. B. Acutimitoceras sinulobatum n. sp., MB.C.5465.2. C. Acutimitoceras sinulobatum n. sp., MB.C.5465.11. D. Actutimitoceras sinulobatum n. sp., MB.C.5465.12. E. Acutimitoceras sp. A, MB.C.5466.1. F. Acutimitoceras algeriense n. sp. MB.C.5463.2, at $14.1 \mathrm{~mm} \mathrm{dm}, 8.0 \mathrm{~mm}$ ww, $8.4 \mathrm{~mm}$ wh. G. Acutimitoceras algeriense n. sp., MB.C.5464.7, at $8.8 \mathrm{~mm} \mathrm{dm}, 5.3 \mathrm{~mm}$ ww, $4.8 \mathrm{~mm}$ wh. H. Acutimitoceras sinulobatum n. sp., MB.C.5465.1, at $10.2 \mathrm{~mm} \mathrm{dm}, 7.2 \mathrm{~mm}$ ww, $5.4 \mathrm{~mm}$ wh. I. Acutimitoceras sinulobatum n. sp., MB.C.5475.6, at $8.3 \mathrm{~mm} \mathrm{dm}, 6.4 \mathrm{~mm}$ ww, $4.4 \mathrm{~mm}$ wh. J. Acutimitoceras sp. A. MB.C. 5466.5 , at $11.0 \mathrm{~mm} \mathrm{dm}, 6.8 \mathrm{~mm}$ ww, $5.7 \mathrm{~mm}$ wh.

lobe. Species of Nicimitoceras Korn, 1993 are similar in aperture height, but these always possess an external lobe that is much shorter than the adventive lobe, a narrower ventrolateral saddle, and an asymmetric adventive lobe.

The most similar species are obviously those described and revised by Miller \& Furnish (1951) from the "Middle" Tournaisian (late Kinderhookian) Chouteau Limestone of Missouri. Acutimitoceras abundans (Miller \& Collinson, 1951), A. compressum (Moore, 1928), A. jessiae (Miller \& Gurley, 1896), and $A$. discoidale (Smith, 1903) have similar suture lines and conch forms in adult stages, but the morphology of the inner whorls is not known. Of these four species, $A$. discoidale and $A$. jessiae are easily separable from $A$. algeriense by their steinkern constrictions. $A$. abundans has simple constrictions which run with convex course across flanks and venter, and $A$. compressum has a thinner conch (ww/dm appr. 0.34), in contrast to a ratio of approximately 0.45 to 0.55 in adult specimens of $A$. algeriense.

\section{Acutimitoceras sinulobatum n. sp.}

Derivation of name: After the sinuous course of the suture line.

Holotype: Specimen MB.C.5465.1; figured here in Fig. 3G, H.

Type locality and horizon: Dry plain immediately northeast of the Gara el Kahla, $35 \mathrm{~km}$ southwest of Timimoun, Gourara, Algeria; claystone horizon in the Grès supérieurs de Kahla, probably middle part of the Early Tournaisian.

Material: 44 specimens between 6 and $13 \mathrm{~mm}$ conch diameter.

Diagnosis: Species of Acutimitoceras with pachyconic conch. Inner whorls up to $5 \mathrm{~mm}$ diameter with open umbilicus (uw/dm 0.20), umbilicus closed in later stages. Aperture low, whorl expansion rate 1.60 to 1.70 at diameters greater than $5 \mathrm{~mm}$. Steinkern with linear constrictions. Suture line with moderately wide, parallel-sided 

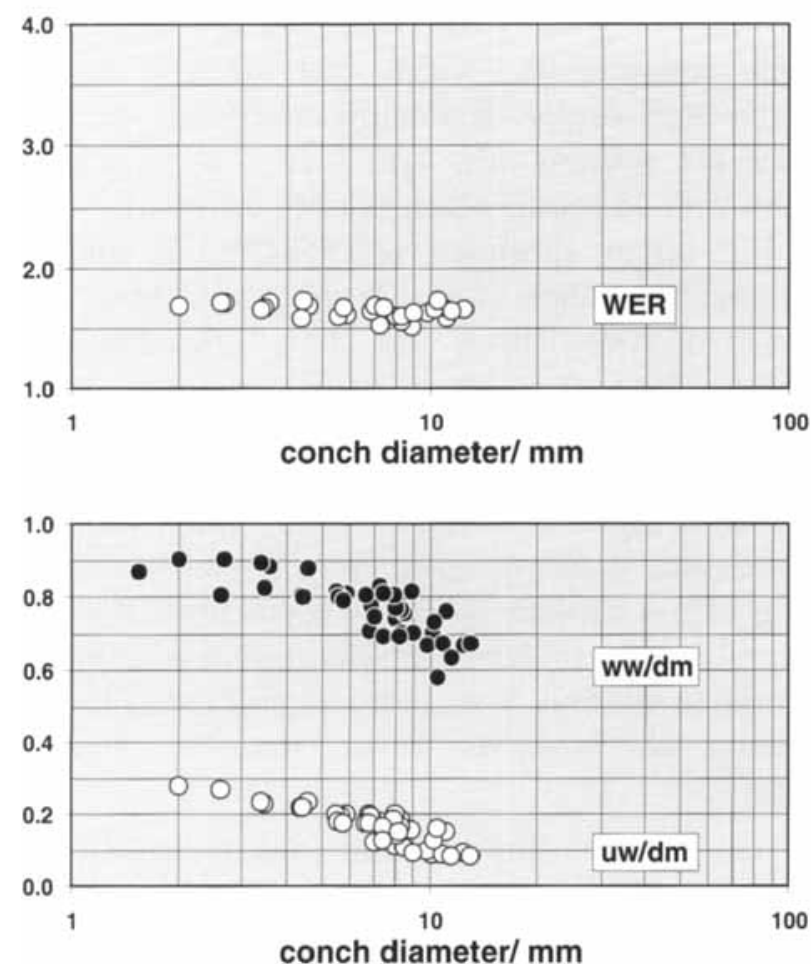

Fig. 6. Bivariate plot of whorl expansion rate (WER) as well as whorl width/conch diameter and umbilical width/conch diameter ratios of Acutimitoceras sinulobatum n. sp.

external lobe and broadly rounded adventive lobe.

Description: The bivariate plot (Fig. 6) shows that there are almost no ontogenetic changes in the whorl expansion rate between 2 and $12 \mathrm{~mm}$ conch diameter, and that always a value of 1.6 to 1.7 is realised. Only some specimens between 7 and $9 \mathrm{~mm}$ diameter have a slightly lower aperture. The umbilicus closes continuously during ontogeny; between 2 and $12 \mathrm{~mm}$ conch diameter, the $\mathrm{uw} / \mathrm{dm}$ ratio is lowered from 0.30 to 0.08 , but there is some intraspecific variability noticeable. The same changes can be observed in the whorl width ratio, that is rather constant up to $6 \mathrm{~mm}$ diameter at a level of 0.80 , but then decreases to 0.60 at $12 \mathrm{~mm}$ conch diameter.

Three specimens were sectioned (Fig. 5B-D); they share some common characteristics but show also some differences. The inner whorls are preserved in specimen MB.C.5465.12 and display a widely umbilicated initial stage and the stagnation of umbilical opening already in the third whorl (appr. $6 \mathrm{~mm}$ conch diameter). The whorl section is crescent-shaped in this globular stage, with low aperture. The larger specimens MB.C.5465.2 and MB.C.5465.11 differ in the thickness of the whorl, but otherwise are similar in the value of the apertural height and umbilical width. At $11 \mathrm{~mm}$ conch diameter, the whorl width ratio is 0.76 in specimen MB.C.5465.2, which is among the thickest specimens within the sample, and only 0.63 in specimen MB.C.5465.11, which belongs to the most discoidal individuals. Intermediates between these two extreme specimens demonstrate the wide variability within this species.

Holotype MB.C.5465.1 has almost $12.5 \mathrm{~mm}$ conch diameter; it is completely chambered with 19 septa. Conch form is pachyconic (ww/dm 0.67 ), and the funnel-shaped umbilicus is very narrow (uw/dm 0.09) with an oblique umbilical wall. Three constrictions are arranged approximately $90^{\circ}$ apart, and one half of the whorl is smooth. The constrictions are almost linear without ventral sinus; they are not particularly strong. Ornament consists of linear growth line relicts impressed on the steinkern.

Paratype MB.C.5465.5 possesses constrictions which are very weak on the inner flank and become deeper in the ventral area. The umbilical margin is not funnel-shaped in this specimen; at $10 \mathrm{~mm}$ conch diameter, it is almost continuously rounded. Radial ornament is preserved in paratype MB.C.5465.3.

In the ontogenetic development of the suture line between 8 and $10 \mathrm{~mm}$ diameter, a transformation of the wide V-shaped external lobe towards an almost lanceolate external lobe can be seen (Fig. $5 \mathrm{H}, \mathrm{I}$ ). In the latter, the flanks still diverge, and the external lobe is wider than in other species of Acutimitoceras within the assemblage from the Gara el Kahla. The adventive lobe is rounded in both ontogenetic stages, and the ventrolateral saddle has the inverted shape of the adventive lobe.

Discussion: Acutimitoceras sinulobatum differs from all other known species of the genus by its combination of a pachyconic conch and a suture line with a rounded adventive lobe. Of the other species, Acutimitoceras depressum (Vöhringer, 1960) resembles the new species in conch shape, but its inner whorls are more evolute.

\section{Acutimitoceras sp. A}

Material: 59 specimens between 9 and $16 \mathrm{~mm}$ conch diameter.

Description: Only few complete specimens are available, and hence little can be said about intraspecific variability (Fig. 7). Ontogenetic modifications, however, are striking, especially in 

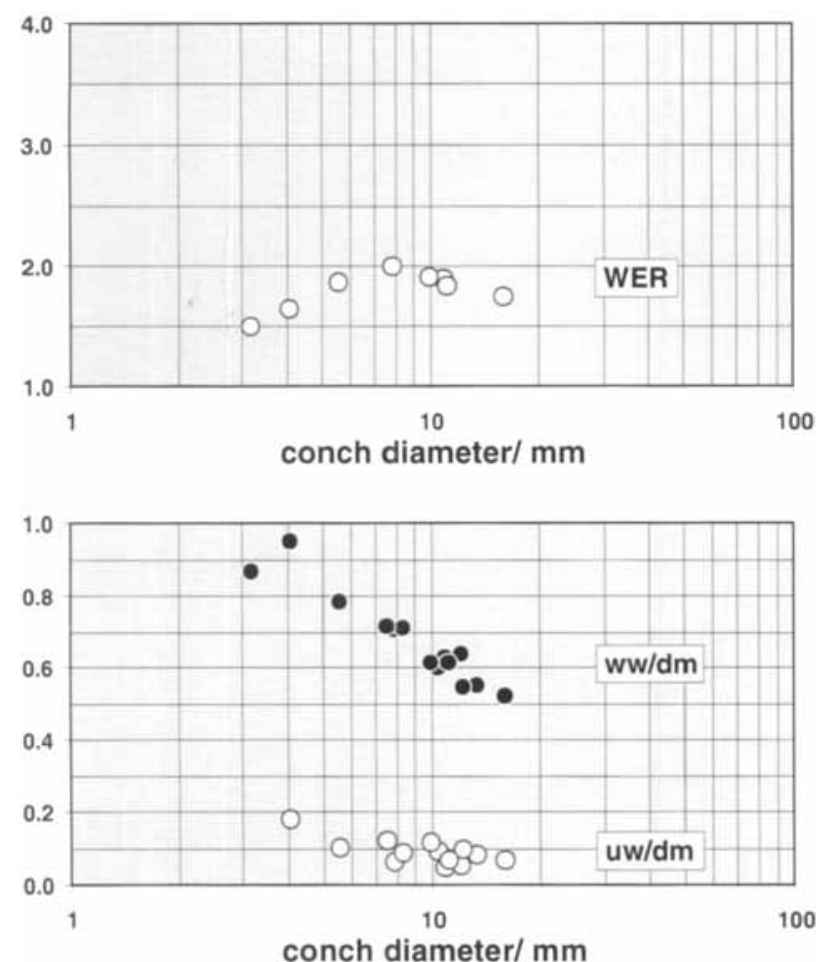

Fig. 7. Bivariate plot of whorl expansion rate (WER) as well as whorl width/conch diameter and umbilical width/conch diameter ratios of Acutimitoceras sp. A.

the whorl expansion rate and whorl width ratio. The first is low in early stages $(1.5$ at $3 \mathrm{~mm} \mathrm{dm})$. but there is a remarkable increase to 2.00 at $8 \mathrm{~mm} \mathrm{dm}$, and a slight decrease in specimens larger than $11 \mathrm{~mm}$ conch diameter. In the development of the conch width, a relatively rapid lowering from $0.90(3-4 \mathrm{~mm} \mathrm{dm})$ to $0.50(17 \mathrm{~mm}$ $\mathrm{dm})$ can be observed. Since only stages above $4 \mathrm{~mm}$ conch diameter could be analysed, the umbilical closing can not be expressed in the diagram. It can be noticed that between 8 and $18 \mathrm{~mm}$ conch diameter, the relative umbilical width is rather constant at 0.07 .

The cross section of specimen MB.C.5466.1 (Fig. 5E) displays the marked ontogenetic conch modifications within a span of only three whorls, where the crescent-shaped whorl cross section of the juvenile stage ( $3 \mathrm{~mm}$ conch diameter) is transformed into a laterally compressed section with remarkably heightened aperture, expressed in the increase of the whorl expansion rate from 1.50 to almost 2.00. The whorl cross section shows, at $11 \mathrm{~mm}$ conch diameter, slightly flattened flanks that converge slightly to a widely rounded venter.

Specimen MB.C. 5466.5 is, at $11 \mathrm{~mm}$ conch diameter, pachyconic (ww/dm 0.62$)$ with a very narrow, funnel-shaped umbilicus (uw/dm 0.07) where the conch is thickest. Flanks and venter are widely rounded. The specimen has two steinkern constrictions, which run straight across flanks and venter. Remnants of convex growth lines are present. The specimen is a phragmocone with 15 septa, which are not crowded.

The larger specimen MB.C.5476.2 is almost identical in conch ratios. It does not show any traces of constrictions and has 14 chambers on one volution. A fragment of the same size (specimen 237) shows one constriction.

The suture line of a specimen of $11 \mathrm{~mm}$ conch diameter (specimen MB.C.5466.5) has a narrow, lanceolate external lobe with parallel flanks (Fig. 5J). A broadly rounded, asymmetric ventrolateral saddle follows, and the adventive lobe of the same width is V-shaped and pointed. The adventive lobe is slightly shorter than the external lobe.

Discussion: These forms are described in open nomenclature because only a few specimens are available for study. Many known species of Acutimitoceras share a similar conch morphology with laterally compressed conchs, and separation is only possible when diagnostic characteristics are preserved.

\section{Hasselbachia Korn \& Weyer, 2003}

Type species: Imitoceras multisulcatum Vöhringer, 1960.

\section{Hasselbachia gourara n. sp.}

Derivation of name: After the Gourara region, where the material was collected.

Holotype: Specimen MB.C.5467.4; figured here in Fig. 8A, B.

Type locality and horizon: Dry plain immediately northeast of the Gara el Kahla $35 \mathrm{~km}$ southwest of Timimoun, Gourara, Algeria; claystone horizon in the Grès supérieurs de Kahla, probably middle part of the Early Tournaisian.

Material: 13 specimens between 4.5 and $8 \mathrm{~mm}$ conch diameter.

Diagnosis: Species of Hasselbachia with minute discoidal conch. Inner whorls up to $5 \mathrm{~mm}$ diameter widely umbilicate (uw/dm 0.50 ), umbilicus narrower in later stages. Aperture very low, whorl expansion rate 1.50 . Steinkern without constrictions. Suture line with wide, parallelsided external lobe. 

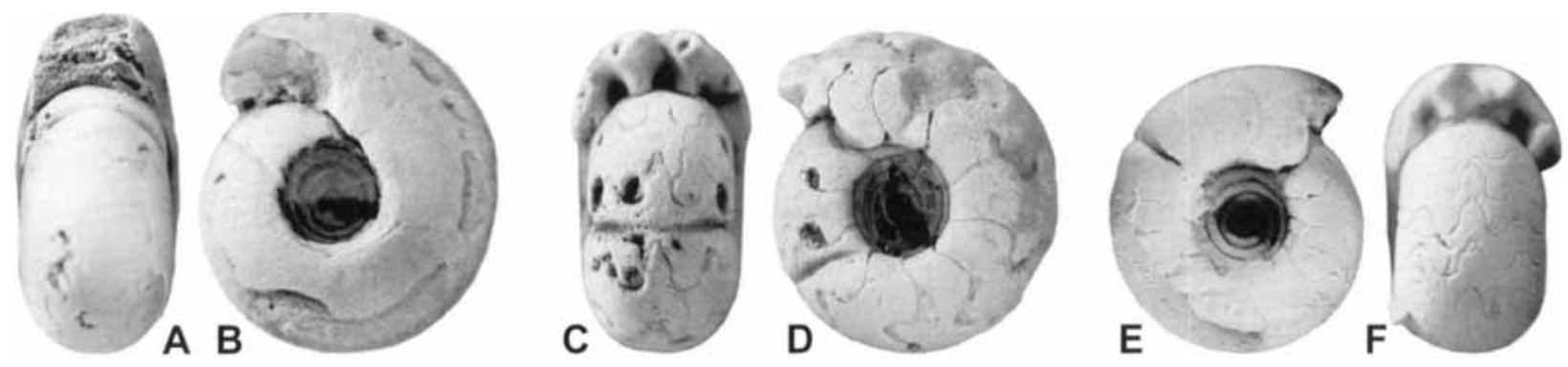

Fig. 8. Hasselbachia gourara n. sp. from the Grès supérieurs de Kahla of the Gara el Kahla, all coll. Ebbighausen, Bockwin$\mathrm{kel}$, and Korn 2003. A, B. MB.C.5467.4, dorsal and lateral views, $\times$ 5. C, D. MB.C.5467.3, dorsal and lateral views, $\times 5$. E, F. MB.C.5467.5, lateral and dorsal views, $\times 5$.

Description: In the characters whorl expansion rate, relative umbilical width, and whorl width ratio, very little variability can be recognised, but ontogenetic changes in the latter two characters are well expressed (Fig. 9). All stages have a low aperture (WER usually around 1.50), but the umbilicus is constant between 2 and $5 \mathrm{~mm}$ conch diameter (uw/dm 0.50 ), with a sudden decrease to 0.3 at $8 \mathrm{~mm} \mathrm{dm}$. A reduction in the whorl width index, that is constant around 0.7 up to $5 \mathrm{~mm}$ conch diameter, to 0.48 at $8 \mathrm{~mm}$ $\mathrm{dm}$ is visible.

The cross section of specimen MB.C.5467.2 (Fig. 10A) portrays the ontogeny of the inner whorls, and it reveals that the morphology hardly changes between 1.5 and $5 \mathrm{~mm}$ conch diameter. The whorls have a semilunate cross sec-
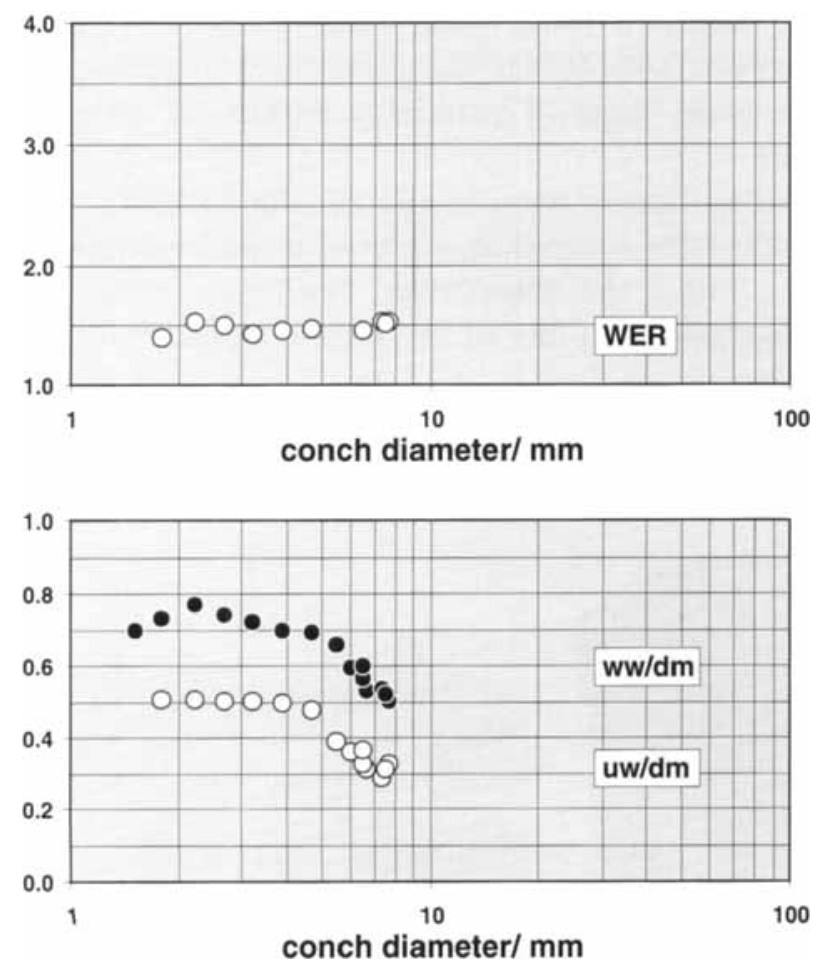

Fig. 9. Bivariate plot of whorl expansion rate (WER) as well as whorl width/conch diameter and umbilical width/conch diameter ratios of Hasselbachia gourara n. sp. tion at this stage, with very low aperture (WER constantly 1.50 ). There is a continuous opening of the umbilicus, and hence the uw/dm ratio shows always a value of 0.50 .

Holotype MB.C.5467.4 is a specimen of less than $8 \mathrm{~mm}$ conch diameter, in which approximately $300^{\circ}$ of the body chamber are preserved. The final two septa exhibit approximation. The conch is discoidal (ww/dm 0.52 ) with very low aperture (WER 1.52), and attains a maximum width near the umbilical margin. A moderately wide umbilicus (uw/dm 0.31) has a steep umbilical wall and a well-defined umbilical margin. One linear steinkern constriction can be seen; it begins at the umbilical margin. On the flanks of the body chamber, extremely fine radial lines which run in rursiradiate direction can be traced, they are best visible on the inner flank.

Two linear and slightly rursiradiate constrictions are visible in paratype MB.C.5467.5, they are deepest in the inner flank and become weaker on the outer flank and venter. This specimen has $6.5 \mathrm{~mm}$ conch diameter and is fully chambered; 15 septa are arranged in equal distances.

Two suture lines were drawn (Fig. 10B, C), they show very similar outlines at an ontogenetic stage of approximately $7.5 \mathrm{~mm}$ diameter. Both specimens possess a wide lanceolate external lobe (wider than the ventrolateral saddle) with barely diverging flanks and mammiform base. The adventive lobe is as wide as the ventrolat-
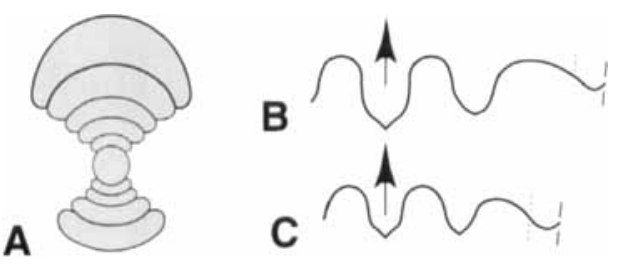

Fig. 10. Cross section $(\mathrm{A} ; \times 4)$ and suture lines $(\mathrm{B}, \mathrm{C} ; \times 6)$ of Hasselbachia gourara n. sp. from the Grès superieurs de Kahla of the Gara el Kahla. A. MB.C.5467.2. B. MB.C.5467.5, at $7.5 \mathrm{~mm} \mathrm{dm}, 3.9 \mathrm{~mm} \mathrm{ww}, 3.0 \mathrm{~mm}$ wh. C. MB.C. 5467.4 , at $3.7 \mathrm{~mm} w w, 2.7 \mathrm{~mm}$ wh. 
eral saddle and has an angular base. The septal approximation suggests that the specimens, although small, are adults.

Discussion: Hasselbachia multisulcata (Vöhringer, 1960) and H. sphaeroidalis (Vöhringer, 1960) have globular or pachyconic conchs and are thus easily separable from the new species. $H$. gracilis (Vöhringer, 1960) has a similar though slightly thicker conch (ww/dm $0.55-0.60)$ than $H$. gourara (ww/dm 0.50 ), and possesses numerous short constrictions on the flanks, unlike $H$. gourara which has simple, wide-standing steinkern constrictions.

\section{Family Gattendorfiidae Bartzsch \& Weyer, 1987 Subfamily Gattendorfiinae Bartzsch \& Weyer, 1987}

\section{Gattendorfia Schindewolf, 1920}

Type species: Goniatites subinvolutus Münster, 1839.

\section{Gattendorfia jacquelinae n. sp.}

1984 Gattendorfia gr. crassa - Conrad: 131, pl. 5: Figs 1. 2.

1985 Gattendorfia ex gr. crassa - Lemosquet et al.: pl. 10: Figs 1, 2.

Derivation of name: After Jacqueline Conrad (Marseille), in recognition to her pioneering work on the Carboniferous stratigraphy of the Algerian Sahara.

Holotype: Specimen MB.C.5462.1 (coll. Legrand-Blain); figured here in Fig. 11A, B.

Type locality and horizon: Dry plain immediately northeast of the Gara el Kahla, $35 \mathrm{~km}$ southwest of Timimoun, Gourara, Algeria; claystone horizon in the Grès supérieurs de Kahla, probably middle part of the Early Tournaisian.
Material: 169 specimens between 4.5 and $16 \mathrm{~mm}$ conch diameter.

Diagnosis: Species of Gattendorfia with discoidal to pachyconic conch. Inner whorls up to $8 \mathrm{~mm}$ diameter widely umbilicate (uw/dm 0.50 ), umbilicus narrower (uw/dm 0.40) at $15 \mathrm{~mm}$ diameter. Aperture low, whorl expansion rate 1.50-1.60. Umbilical margin rounded. Steinkern with rursiradiate constrictions. Suture line with lanceolate external lobe and symmetric adventive lobe.

Description: In the bivariate diagrams that express the ontogenetic changes and intraspecific variability (Fig. 12), major differences in the pattern are recognisable. A character that does not change during ontogeny, and that displays only little variability is the whorl expansion rate that is constant at a value of 1.50 to 1.60 . In contrast to this, the umbilical width changes throughout ontogeny, as characteristic for Gattendorfia, and has the highest value at a conch diameter of $4 \mathrm{~mm}$, when a maximum of 0.55 can be reached. Later in ontogeny, this ratio is reduced to 0.40 at $15 \mathrm{~mm}$ conch diameter. At $10 \mathrm{~mm}$ conch diameter, the umbilical width ratio ranges from 0.40 to 0.50 . Even more variable than the umbilical width is the conch shape index (ww/dm). After a discoidal juvenile stage up to approximately $6 \mathrm{~mm}$ conch diameter, a thickly discoidal shape is characteristic (ww/dm $0.45-0.60)$; in later stages, a more pachyconic shape is typical (ww/dm 0.60-0.75). These numbers demonstrate the wide range of variability within the population.

Two specimens were sectioned (Fig. 13A, B), and both show somewhat extreme conch morphologies within the population. The larger specimen MB.C.5468.2 is one of the thicker variants with a narrower umbilicus, and the smaller specimen MB.C.5468.1 belongs to the narrower, widely
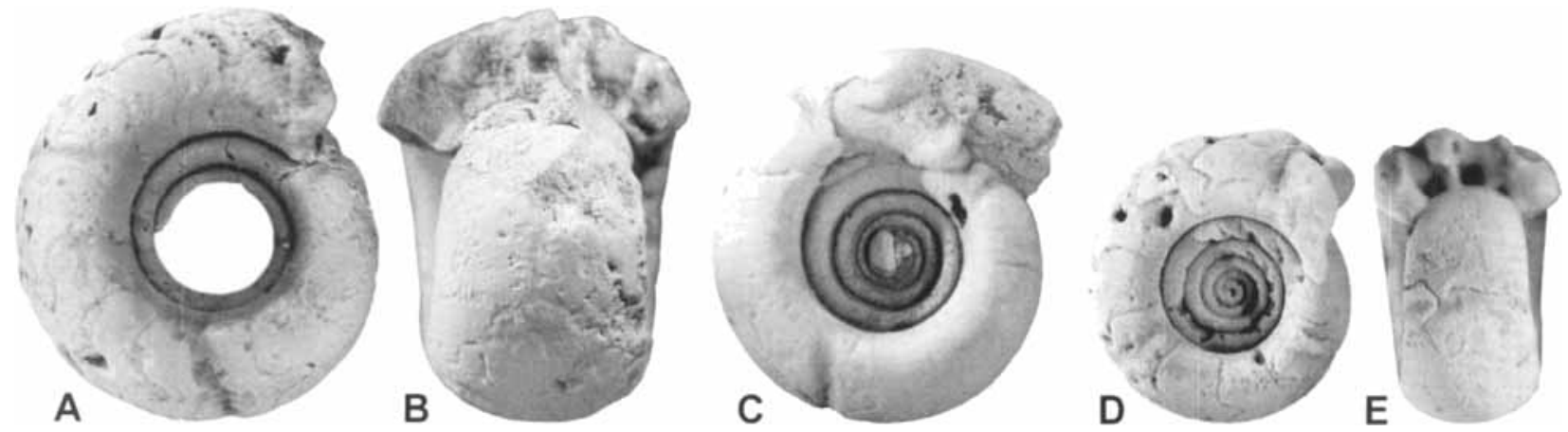

Fig. 11. Gattendorfia jacquelinae n. sp. from the from the Grès supérieurs de Kahla of the Gara el Kahla, all coll. Ebbighausen, Bockwinkel, and Korn 2003, except for fig. A, B (coll. Legrand-Blain 1968). A, B. MB.C.5462.1, lateral and dorsal views, $\times$ 3. C. MB.C.5468.12, lateral view, $\times$ 4. D, E. MB.C.5468.49, lateral and dorsal views, $\times 4$. 

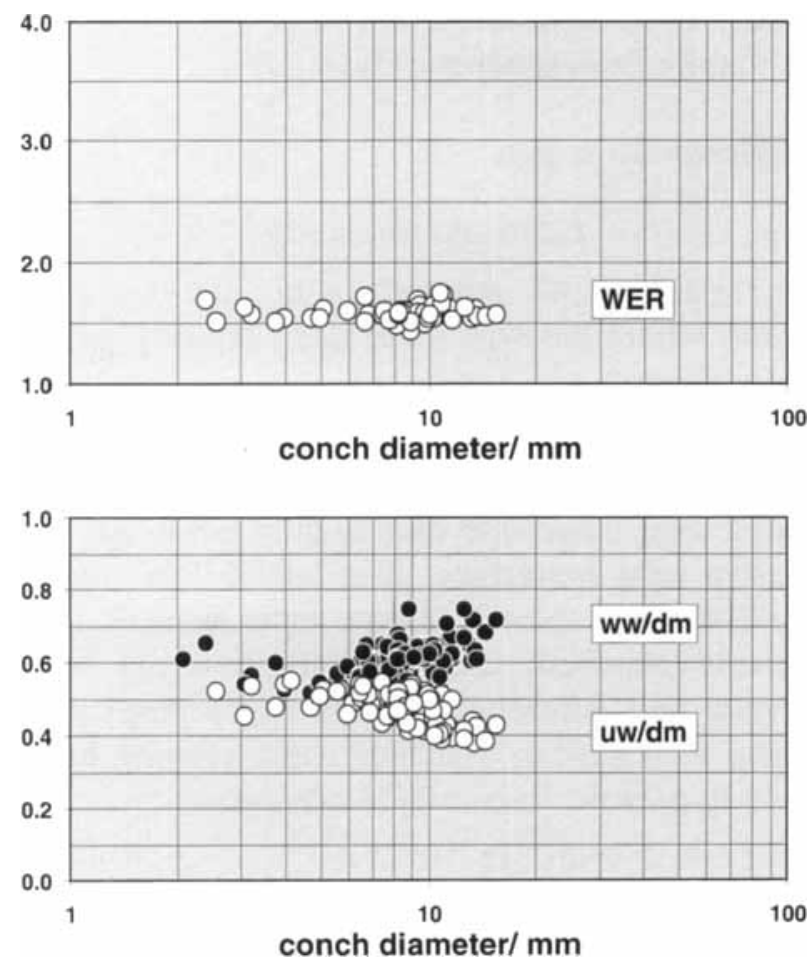

Fig. 12. Bivariate plot of whorl expansion rate (WER) as well as whorl width/conch diameter and umbilical width/ conch diameter ratios of Gattendorfia jacquelinae n. $\mathrm{sp}$.

umbilicate individuals. Both have semilunate whorls with broadly rounded ventral sides, and only specimen MB.C.5468.2 shows an indication of an angular umbilical margin.

The largest available specimen MB.C.5462.1 $(16 \mathrm{~mm} \mathrm{dm})$ was chosen as the holotype; it is a chambered steinkern with 12 septa in the last volution. Its pachyconic conch (ww/dm 0.72 ) has a moderately wide umbilicus (uw/dm 0.43), with broadly rounded venter, pronounced subangular umbilical margin, and almost vertical umbilical wall. The last whorl has a subtrapezoidal whorl cross section and embraces the preceding almost to its umbilical edge. Two constrictions are visible, they begin at the umbilical edge and turn slightly back to form a shallow and broad ventral sinus.

Paratype MB.C.5468.12 is representative of the more narrow specimens; at $10 \mathrm{~mm}$ conch diameter it is thickly discoidal (ww/dm appr. 0.55). In this growth stage, the umbilical margin is still rounded and only a weak indication of angularity can be recognised. The last volution of the phragmocone is composed of eight septa. Three steinkern constrictions are arranged in irregular distances; they begin at the umbilical margin, turn slightly back and run in linear direction across the venter.

A second paratype MB.C.5468.49 resembles the conch shape of paratype MB.C.5468.12. At $8 \mathrm{~mm}$ conch diameter is pachyconic (ww/dm 0.62 ) and widely umbilicate (uw/dm 0.46 ) with the beginning of umbilical margin sharpening.

Suture lines of three specimens (Fig. 13D-F) show relatively similar outlines. Between 8 and approximately $16 \mathrm{~mm}$ conch diameter, no dramatic changes can be recognised, except for a continous deepening of the adventive lobe. The external lobe is slightly pouched in the adult stage, the ventrolateral saddle is almost symmetric and widely rounded, and the lanceolate adventive lobe is asymmetric with more sinuous dorsal flank.
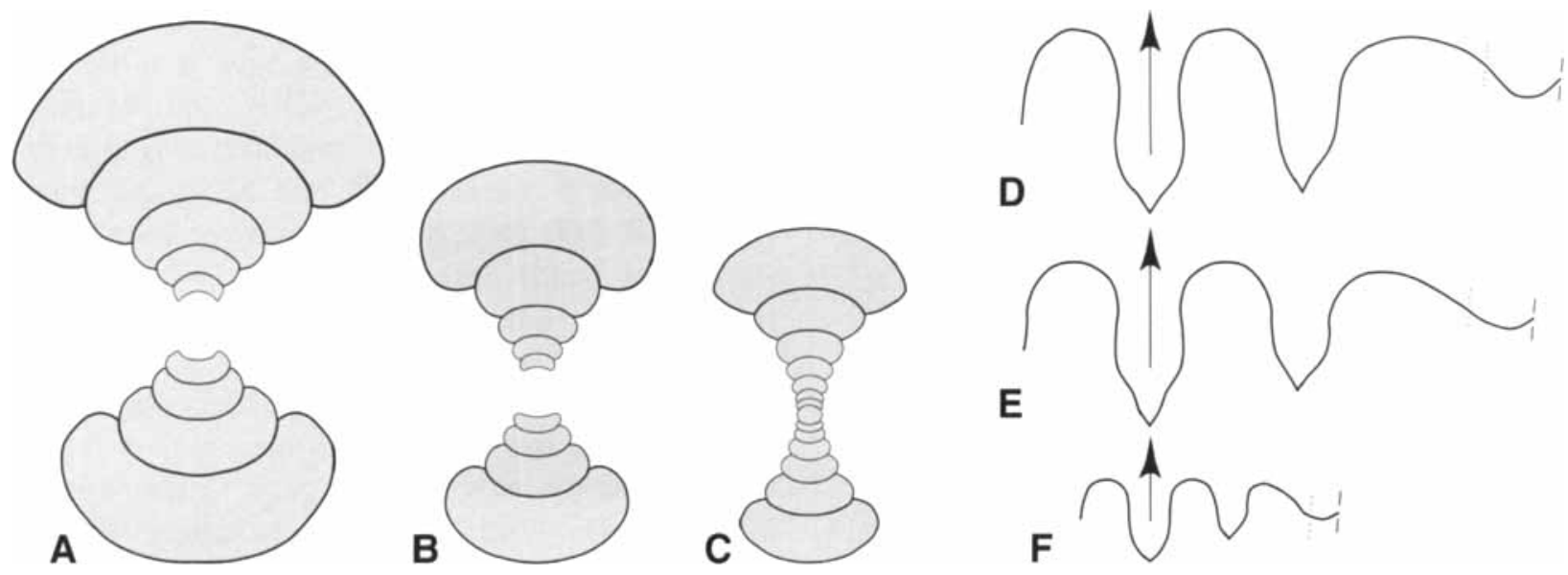

Fig. 13. Cross sections $(\mathrm{A}-\mathrm{C} ; \times 4)$ and suture lines $(\mathrm{D}-\mathrm{F} ; \times 6)$ of species of Gattendorfia from the Grès supérieurs de Kahla of the Gara el Kahla. A. Gattendorfia jacquelinae n. sp., MB.C.5468.2. B. Gattendorfia jacquelinae n. sp., MB.C.5468.1. C. Gattendorfia cf. crassa Schmidt, 1924, MB.C.5469. D. Gattendorfia jacquelinae n. sp., MB.C5468.56, at $10.1 \mathrm{~mm} \mathrm{ww}, 3.9 \mathrm{~mm}$ wh. E. Gattendorfia jacquelinae n. sp., MB.C. 5468.23 , at $8.1 \mathrm{~mm}$ ww, $4.3 \mathrm{~mm}$ wh. F. Gattendorfia jacquelinae n. sp., MB.C. 5468.21 , at $8.5 \mathrm{~mm} \mathrm{dm}, 4.9 \mathrm{~mm}$ ww, $2.2 \mathrm{~mm}$ wh. 
Discussion: Gattendorfia jacquelinae resembles G. costata Vöhringer, 1960 in general conch form but lack ribs. Also, G. costata has a much more pronounced umbilical margin which is more rounded in $G$. jacquelinae. $G$. crassa Schmidt, 1924 differs from the new species by its much more widely umbilicate early whorls (uw/ $\mathrm{dm}$ more than 0.60 )

\section{Gattendorfia cf. crassa Schmidt, 1924}

Material: One specimen (MB.C.5469) of nearly $9 \mathrm{~mm}$ diameter.

Description: The single specimen was sectioned (Fig. 13C); it displays the complete ontogeny up to $8 \mathrm{~mm}$ conch diameter (Fig. 14). Seven whorls are present at this stage, with a wide umbilicus (uw/dm 0.50 to 0.60 ), and with crescentshaped whorl section. In the last whorl, a pronounced angular umbilical margin is developed, and the cross section becomes subtrapezoidal.

Discussion: The single available specimen differs from $G$. jacquelinae by its wider umbilicus and sharp umbilical margin. Since only one incompletely preserved specimen is available, a certain assignment to $G$. crassa is impossible. $G$. crassa, however, has by far the most similar conch morphology.
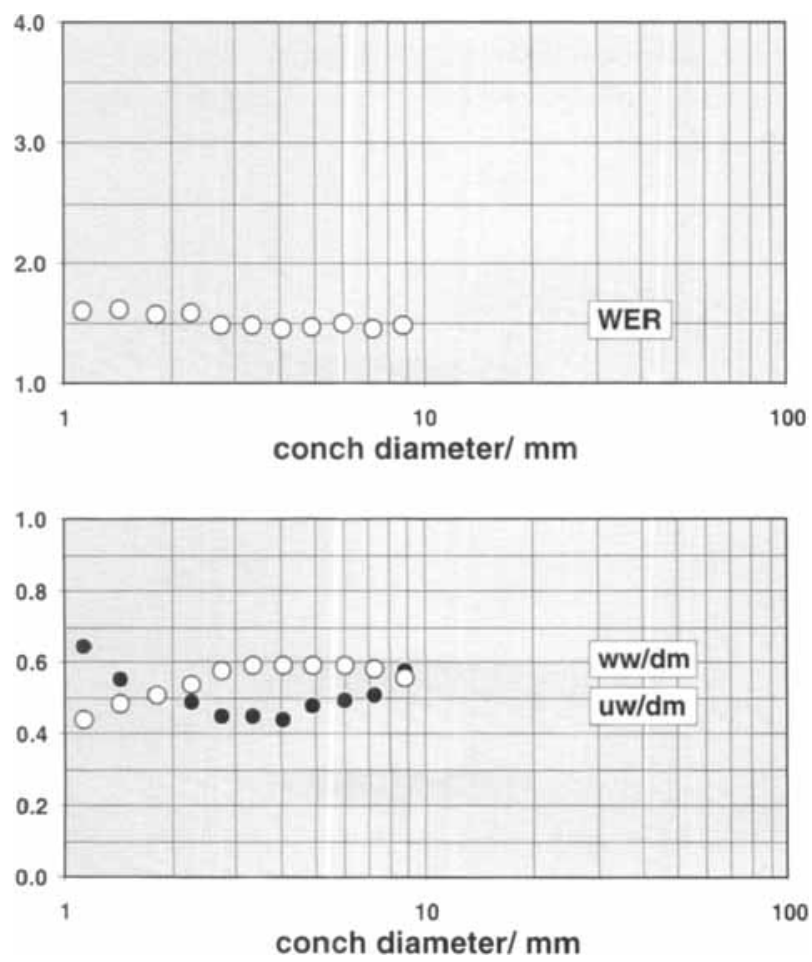

Fig. 14. Bivariate plot of whorl expansion rate (WER) as well as whorl width/conch diameter and umbilical width/conch diameter ratios of Gattendorfia cf. crassa Schmidt, 1924.

\section{Family Prolecanitidae Hyatt, 1884}

Subfamily Prolecanitinae Hyatt, 1884

\section{Kahlacanites n. gen.}

Type species: Kahlacanites mariae $\mathbf{n}$. sp.

Derivation of name: After the Gara el Kahla, where the type material of the new genus was collected.

Genus definition: Genus of the Prolecanitinae with the suture formula $E A L_{1} L_{2} U$ I; external lobe lanceolate and slightly pouched, adventive lobe lanceolate, first lateral lobe small, hook-shaped, second lateral lobe shallow and broadly rounded, umbilical and internal lobe narrow and lanceolate. Conch shape thinly discoidal to discoidal, umbilical width ranging from wide to narrow. Rectiradiate ornament.

Included species:

Kahlacanites meyendorffi $\mathrm{n}$. sp.

Kahlacanites mariae n. sp.

Kahlacanites timimounensis $\mathrm{n}$. $\mathrm{sp}$.

All three species of the new genus (Fig. 15) were plotted in the same bivariate diagrams (Fig. 16), and can be readily separated on the basis of their relative umbilical widths. In this diagram, three distinct areas are recognisable, with the serpenticonic $K$. meyendorffi more strikingly separated by its wide umbilicus (uw/dm 0.45). $K$. timimounensis is characterised by a narrow umbilicus which in its width ratio is reduced from 0.30 at $2.5 \mathrm{~mm} \mathrm{dm}$ to 0.20 at $14 \mathrm{~mm}$ conch diameter. An intermediate position is occupied by $K$. mariae, in which specimens between 9 and $20 \mathrm{~mm}$ conch diameter possess an umbilical width ratio of approximately 0.30 .

In the whorl expansion rate, there are only two groups separable. Interestingly, it is the intermediate form $K$. mariae (WER 1.80) which is separated from the widely and narrowly umbilicate species $K$. meyendorffi and $K$. timimounensis (WER 2.00 to 2.20), respectively. Regarding the whorl width index, $K$. meyendorffi is separated by its thinner conch (ww/dm 0.30) from the other two species. The plot of $K$.timimounensis, displays an ontogenetic decrease from 0.70 (at $2 \mathrm{~mm} \mathrm{dm}$ ) to $0.38(15 \mathrm{~mm} \mathrm{dm})$.

All three species possess very similar suture lines which differ only to a minor extend (Fig. 17). All have a very narrow, pouched and acute external lobe, followed by a narrowly rounded, asymmetric ventrolateral saddle, a lanceolate adventive lobe which may vary in the degree of sinuosity of the flanks, a rounded asym- 

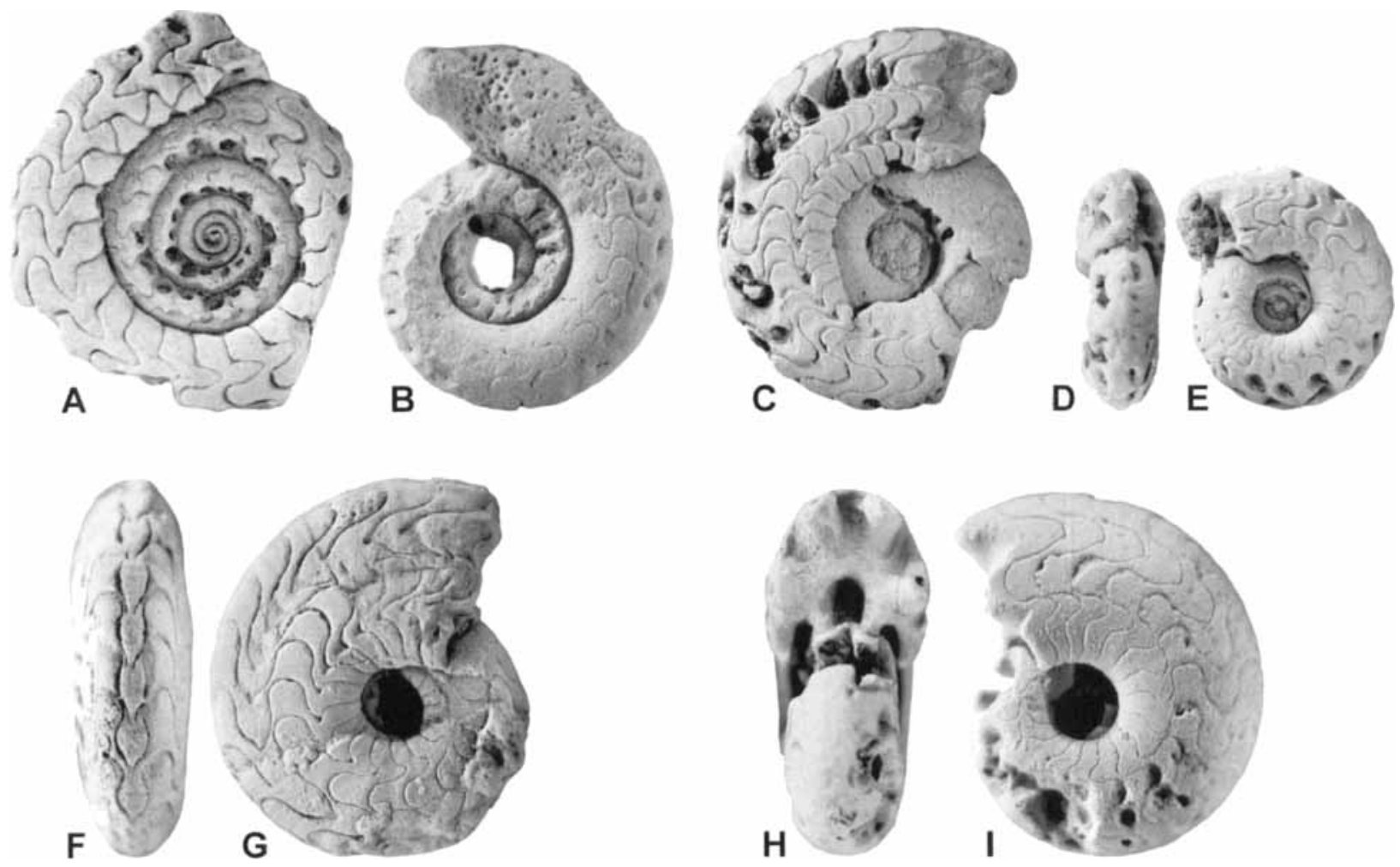

Fig. 15. Species of Kahlacanites from the from the Grès supérieurs de Kahla of the Gara el Kahla, all coll. Ebbighausen, Bockwinkel, and Korn 2003. A. Kahlacanites meyendorffi n. sp., MB.C.5470.2, lateral view, $\times 3$. B. Kahlacanites meyendorffi $\mathrm{n}$. sp., MB.C.5470.1, lateral view, $\times$ 4. C. Kahlacanites mariae n. sp., MB.C.5471.1, lateral view, $\times 2.5$. D, E. Kahlacanites mariae n. sp., MB.C.5471.2, dorsal and lateral views, $\times$ 3. F, G. Kahtacanites timimounensis n. sp., MB.C.5472.6, dorsal and lateral views, $\times$ 4. H, I. Kahlacanites timimounensis n. sp., MB.C. 5472.5, dorsal and lateral views, $\times 5$.
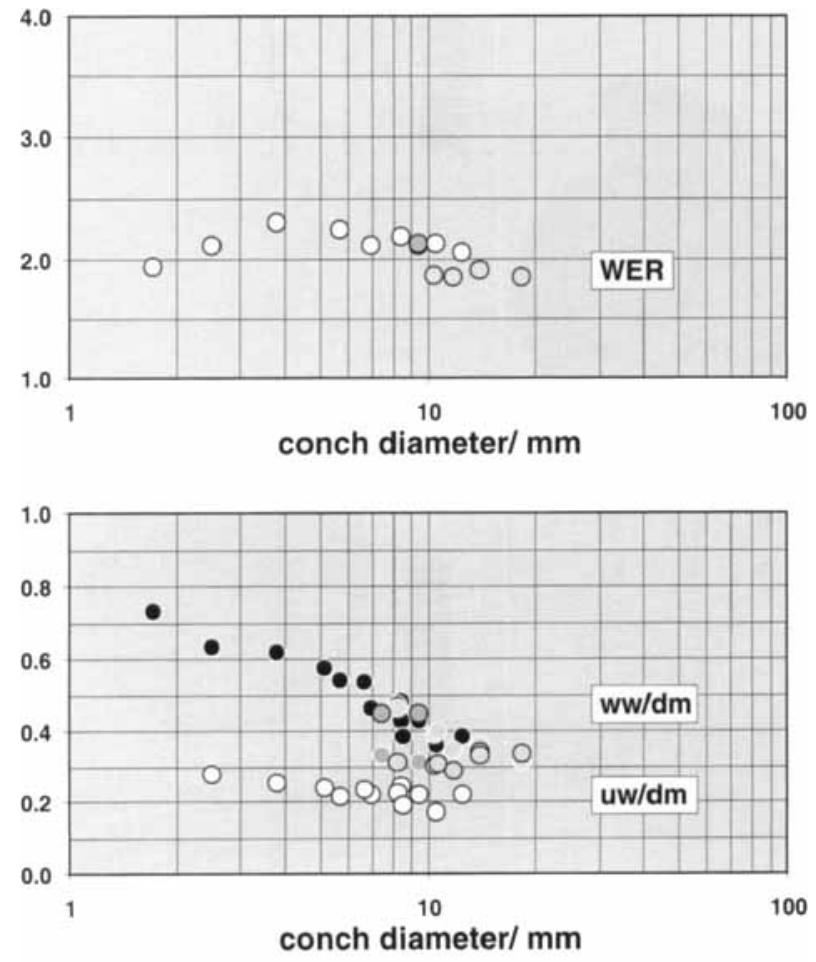

Kahlacanites timimounensis $n . s p$.

O Kahlacanites mariae n. sp.

Kahlacanites meyendorffi n. sp. metric lateral saddle, and a claw-shaped lateral lobe that has a position on the inner flank. On the umbilical wall, an additional, shallow and wide lobe is preserved. In the internal suture line of paratype MB.C.5470.2, a relatively wide, V-shaped umbilical lobe with slightly pouched flanks, and a lanceolate internal lobe are recognisable.

Discussion: Kahlacanites shares several characters with its closest relative Eocanites Librovitch, 1957 (Fig. 18). Both have a lanceolate and sometimes slightly pouched external lobe and a small, claw-shaped lateral lobe. The main differences are the presence of a secondary lateral lobe in Kahlacanites and the tendency within this genus to develop a narrowly umbilicate conch morphology that markedly differs from all other known early prolecanitids. Furthermore, Kahlacanites possesses a radial ornament that runs rectiradiate, not rursiradiate as in Eocanites.

Fig. 16. Bivariate plot of whorl expansion rate (WER) as well as whorl width/conch diameter and umbilical width/conch diameter ratios of Kahlacanites timimounensis n. sp., Kahlacanites mariae n. sp., and Kahlacanites meyendorffi n. sp. 


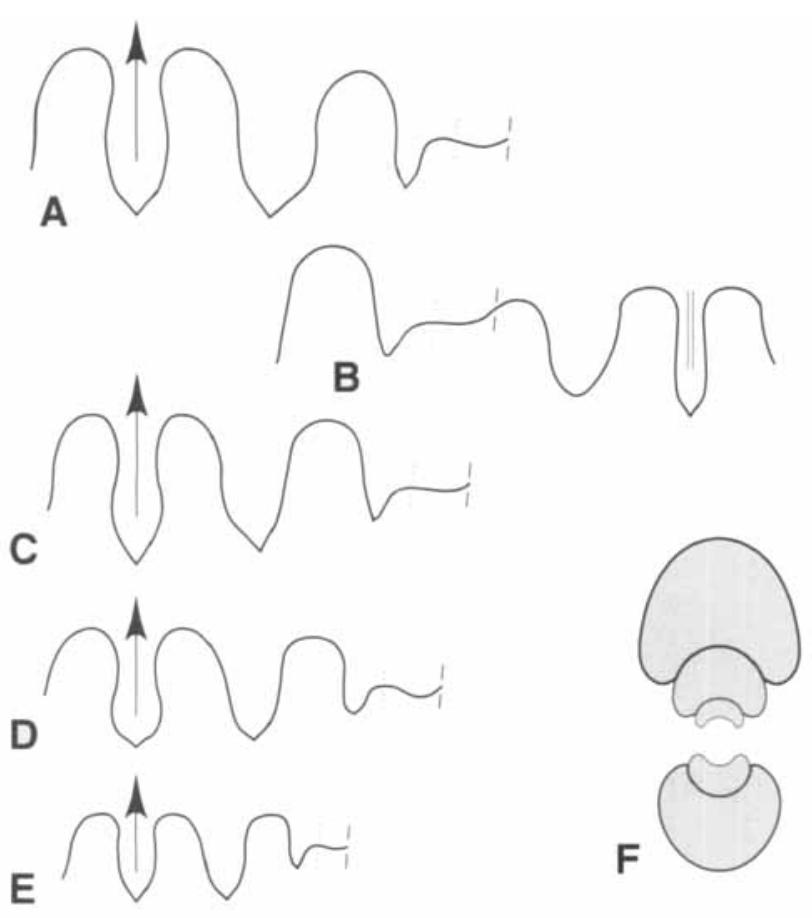

Species of Protocanites Schmidt, 1922 and Becanites Korn, 1997 have, in contrast to Kahlacanites, also a suture line with only one lateral
Fig. 17. Suture lines $(\mathrm{A}-\mathrm{E} ; \times 6)$ and cross section $(\mathrm{F} ; \times 4)$ of species of Kahlacanites from the Grès supérieurs de Kahla of the Gara el Kahla. A. Kahlacanites mariae n. sp., MB.C. 5471.1 , at $13.9 \mathrm{~mm} \mathrm{dm}, 5.0 \mathrm{~mm}$ ww, $5.0 \mathrm{~mm}$ wh. B. Kahlacanites timimounensis n. sp., MB.C. 5470.2 , at $4.7 \mathrm{~mm}$ ww, $5.3 \mathrm{~mm}$ wh. C. Kahlacanites timimounensis $\mathrm{n}$. $\mathrm{sp}$., MB.C.5472.6, at $10.4 \mathrm{~mm} \mathrm{dm}, 4.2 \mathrm{~mm} \mathrm{ww}, 4.7 \mathrm{~mm}$ wh. D. Kahlacanites timimounensis n. sp., MB.C.5472.5, at $9.4 \mathrm{~mm}$ $\mathrm{dm}, 4.0 \mathrm{~mm}$ ww, $4.3 \mathrm{~mm}$ wh. E. Kahlacanites meyendorffi $\mathrm{n}$. sp. MB.C. 5470.1 , at $7.4 \mathrm{~mm} \mathrm{dm}, 2.4 \mathrm{~mm}$ ww, $2.5 \mathrm{~mm}$ wh. F. Kahlacanites timimounensis n. sp., MB.C.5472.1.

lobe, that in both genera is lanceolate and pouched. The external lobe is more pouched in Becanites, and is V-shaped in Protocanites and thus different from Kahlacanites. The next prolecanitid genera with six-lobed suture lines are Merocanites Schindewolf, 1922 (with a V-shaped external lobe) and Michiganites Ruzhencev, 1962 (with a pouched external lobe); however, both possess a deep and lanceolate lateral lobe. Moreover, in these genera, the sixth lobe arises on the dorsal flank of the saddle between the lateral and umbilical lobe, and is thus to be regarded as a secondary umbilical lobe (revised suture line terminology after Korn et al. 2003a).

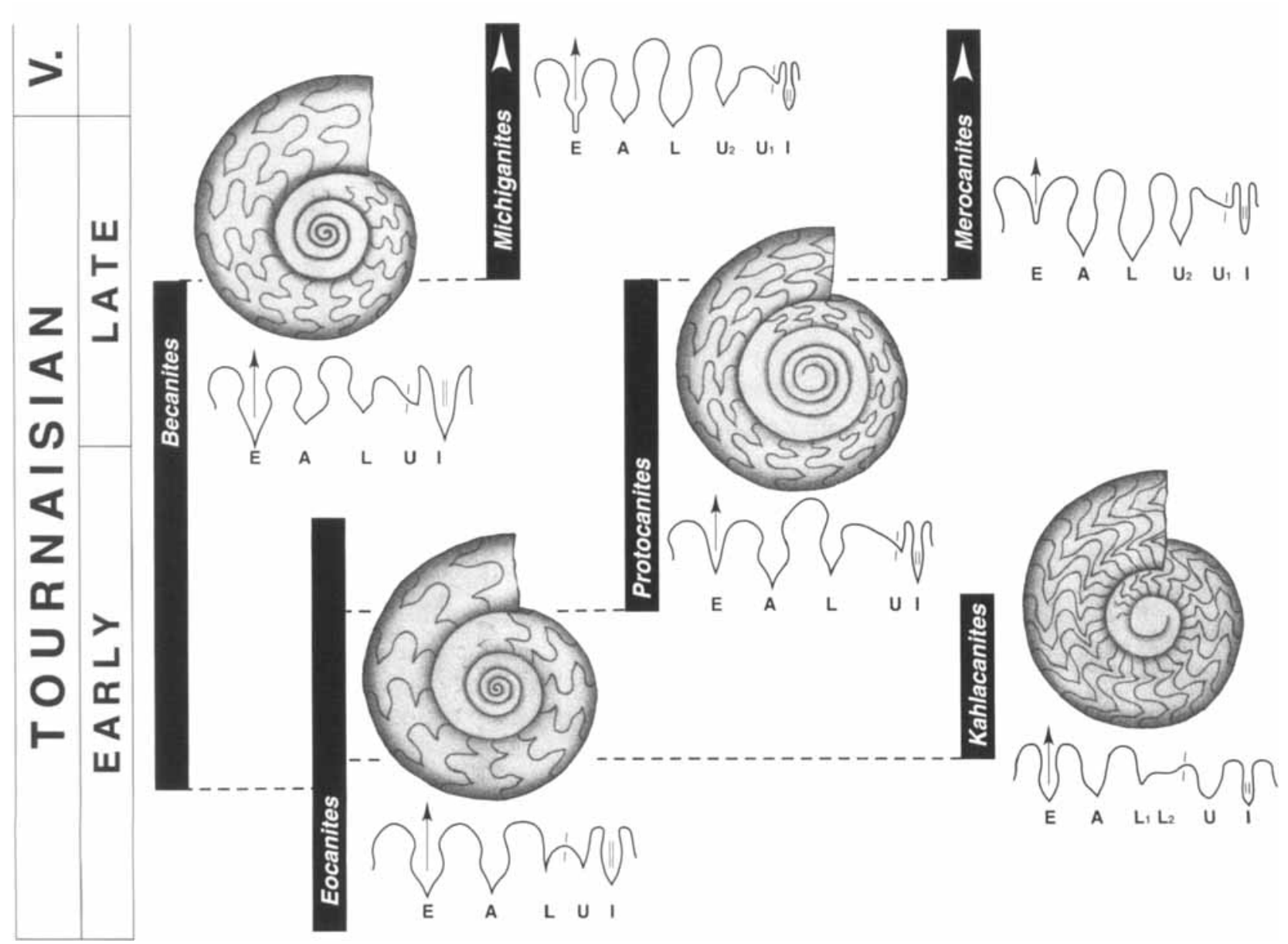

Fig. 18. Possible phylogenetic relationships between the early representatives of the order Prolecanitida. Merocanites, Protocanites, and Michiganites after Miller \& Garner 1955; Becanites after Korn et al. 2003b; Eocanites suture after Korn 1994. 
Stratigraphic occurrence: The absence of any representative of Kahlacanites in the classic German assemblages of the "Gattendorfia Stufe" supports an age determination of the Gara el Kahla ammonoid community younger than the Paragattendorfia patens Zone, i.e. younger part of the Siphonodella sandbergi Zone and/or older part of the Siphonodella crenulata Zone in terms of conodont biozonation.

\section{Kahlacanites meyendorffi n. sp.}

Derivation of name: After André de Meyendorff (1918-1942), who discovered the Gara el Kahla fossil locality.

Holotype: Specimen MB.C.5470.1; figured here in Fig. 15B.

Type locality and horizon: Dry plain immediately northeast of the Gara el Kahla, $35 \mathrm{~km}$ southwest of Timimoun, Gourara, Algeria; claystone horizon in the Grès supérieurs de Kahla, probably middle part of the Early Tournaisian.

Material: 3 specimens, 10.5 and $18 \mathrm{~mm}$ in conch diameter.

Diagnosis: Species of Kahlacanites with wide umbilicus (uw/dm 0.45) and moderately high aperture (WER 2.00-2.20).

Description: Of the two specimens, the holotype is the smaller specimen with $10.5 \mathrm{~mm}$ conch diameter. It is thinly discoidal with almost circular whorl cross section and has a wide umbilicus (uw/dm 0.45). The steinkern is smooth. The larger paratype (MB.C.5470.2) is a fragmentary specimen of approximately $18 \mathrm{~mm}$ conch diameter. Its conch parameters appear to be very similar to the holotype.

\section{Kahlacanites mariae n. sp.}

Derivation of name: After Marie LegrandBlain (Bordeaux), in honour of her contribution to the Carboniferous stratigraphy and brachiopod palaeontology of the Algerian Sahara.

Holotype: Specimen MB.C.5471.1; figured here in Fig. $15 \mathrm{C}$.

Type locality and horizon: Dry plain immediately northeast of the Gara el Kahla, $35 \mathrm{~km}$ southwest of Timimoun, Gourara, Algeria; claystone horizon in the Grès supérieurs de Kahla, probably middle part of the Early Tournaisian.
Material: 12 specimens between 10 and $19 \mathrm{~mm}$ conch diameter.

Diagnosis: Species of Kahlacanites with moderate umbilicus (uw/dm 0.30-0.35) and low aperture (WER 1.85-1.95).

Description: The best preserved and largest specimen MB.C.5471.1 is the holotype, it is a fully septate conch of maximally $18.5 \mathrm{~mm}$ diameter, and the last whorl possesses 26 septa with septal crowding on the last half volution. It is thinly discoidal (ww/dm 0.31 ), with a moderately wide umbilicus (uw/dm 0.34). The whorl section is compressed with a rather low aperture (WER 1.85). A weak undulation caused by faint ribs can be seen on the flanks, and some spiral lines are visible in the midflank area.

A very similar morphology is visible in paratype MB.C.5471.3, which is more corroded and does not display ornament details. It has an umbilicus that is slightly narrower (uw/dm 0.29) than the holotype. The smaller paratype MB.C.5471.2 has maximally $10.5 \mathrm{~mm}$ diameter and displays, on the first third of the last volution, faint and rounded riblets on the flanks. These run with low projection across the inner flank.

\section{Kahlacanites timimounensis n. sp.}

Derivation of name: After the town Timimoun, in which vicinity the specimens where collected.

Holotype: Specimen MB.C.5472.6; figured here in Fig. 15F, G.

Type locality and horizon: Dry plain immediately northeast of the Gara el Kahla, $35 \mathrm{~km}$ southwest of Timimoun, Gourara, Algeria; claystone horizon in the Grès supérieurs de Kahla, probably middle part of the Early Tournaisian.

Material: 11 specimens between 6.5 and $12.5 \mathrm{~mm}$ conch diameter.

Diagnosis: Species of Kahlacanites with narrow umbilicus (uw/dm less than 0.25 in specimens of $12 \mathrm{~mm}$ diameter) and moderately high aperture (WER 2.10-2.30).

Description: The sectioned paratype MB.C.5472.1 (Fig. 17F) expresses the transformation of the whorl cross section in growth stages between 1.5 and $8.5 \mathrm{~mm}$ diameter. The whorl cross section is crescent-shaped with low aperture (WER 1.94) at $1.7 \mathrm{~mm}$ diameter, but within 
one volution, this value raises to a value of 2.31 $(3.8 \mathrm{~mm} \mathrm{dm})$. In this and larger growth stages, the whorl section form is similar, with continuously rounded flanks and venter, and with a rounded umbilical margin.

Holotype MB.C.5472.6 is a phragmocone of $10.5 \mathrm{~mm}$ conch diameter with 18 septa, of which the last are more densely spaced. It is discoidal (ww/dm 0.36), and the laterally compressed whorls are widest in the mid-flank area. Umbilical margin, flanks, and venter are well-rounded. The umbilicus is narrow (uw/dm 0.17), and the aperture moderately high (WER 2.13). The steinkern surface is smooth.

A larger fragment (specimen MB.C.5472.2) is of a specimen of $12.5 \mathrm{~mm}$ diameter. This conch is a little thicker (0.38) than the holotype, and the umbilicus is wider (uw/dm 0.22). The steinkern shows a undulation caused by extremely faint riblets which run with a convex arch across the inner flank.

\section{Acknowledgements}

We are indebted the local authorities of the region of Timimoun for the generous permission for field work. Marie Legrand-Blain (Bordeaux) made her own material available and provided us with information of the geology and stratigraphy around Timimoun. The manuscript profited from the kind reviews by Robert Asher (Berlin), Jürgen Kullmann (Tuibingen), and David Work (Augusta). D.K. has to acknowledge the Deutsche Forschungsgemeinschaft (DFG) for financial support.

\section{References}

Bartzsch, K., Blumenstengel, H. \& Weyer, D. 1999. Stratigraphie des Oberdevons im Thüringischen Schiefergebirge. Teil 1: Schwarzburg-Antiklinorium. - Beiträge zur Geologie von Thüringen, Neue Folge 6: 159-189.

Bartzsch, K. \& Weyer, D. 1982. Zur Stratigraphie des Untertournai (Gattendorfia-Stufe) von Saalfeld im Thüringischen Schiefergebirge. - Abhandlungen und Berichte für Naturkunde und Vorgeschichte (Kulturhistorisches Museum Magdeburg) 12 (4): 3-53 (dated 1981. issued 27. 12. 1982).

- 1987. Die unterkarbonische Ammonoidea-Tribus Pseudarietini. - Abhandlungen und Berichte für Naturkunde und Vorgeschichte (Kulturhistorisches Museum Magdeburg) 13: $59-68$

Bogoslovsky, B. I., Librovitch, L. S. \& Ruzhencev, V. E. 1962. Nadotryad Ammonoidea. Ammonoidei. - In Osnovy Paleontologii, 5, Mollyuski: Golovonogie 1 (Ed. Yu. A. Orlov), Akademiva Nauk SSSR: 243-425.

Conrad, J. 1984. Les séries Carbonifères du Sahara Central Algérien stratigraphie, sédimentation, évolution structurale. - Université de Droit, d' Economie et des Sciences d'Aix Marseille, Thèse de Doctorat d'Etat dès-Sciences naturelles: $370 \mathrm{pp}$; Marseille.

Conrad, J., Pareyn, C. \& Weyant, M. 1970. Mise en évidence du Tournaisien inférieur dans la vallée de la Saoura (Sa- hara nord-occidental) et conséquences paléogéographiques. - Compte Rendus Hebdomadaires des Séances de l'Académie des Sciences [Paris], Serie D: Sciences Naturelles 271 (11): 900-903.

Hollard, H. 1956. Sur le Tournaisien de la vallée du Dra (Sud marocain). - Compte Rendus Hebdomadaires des Séances de l'Académie des Sciences [Paris] 242 (23): 2752-2755.

- 1958. Découverte de Goniatites tournaisiennes dans le Maïder (Province du Tafilalet, Maroc). - Compte Rendus Hebdomadaires des Séances de l'Académie des Sciences 247 (10): 789-792.

Hyatt, A. 1883-1884. Genera of fossil cephalopods. - Proceedings of the Boston Society of Natural History 22: 253-338 (253-272 publ.1883, 273-338 publ.1884).

Jablonski, D. 2002. Survival without recovery after mass extinctions. Proceedings of the National Academy of Science USA 99: 8139-8144.

Ji Qiang 1985. Study on the Phylogeny, Taxonomy, Zonation and Biofacies of Siphonodella (Conodonta). - Bulletin of the Institute of Geology, Chinese Academy of Geological Sciences 11: $51-75$

Korn, D. 1992. Ammonoideen aus dem Devon/KarbonGrenzprofil an der Grünen Schneid (Karnische Alpen, Österreich). - Jahrbuch der Geologischen Bundesanstalt 135 (1): $7-19$

- 1993. The ammonoid faunal change near the DevonianCarboniferous Boundary. - Annales de la Société Géologique de Belgique 115 (for 1992): 581-593.

- 1994. Oberdevonische und unterkarbonische Prionoceraten aus dem Rheinischen Schiefergebirge. - Geologie und Paläontologie in Westfalen 30: 1-85.

- 1997. The Palaeozoic ammonoids of the South Portuguese Zone. - Memórias do Instituto Geológico e Mineiro de Portugal 33: $1-132$.

- 2003. Die Formationen der Kulm-Fazies im Rheinischen Schiefergebirge. - In Amler, M. R. W. \& Gereke, M.: Karbon-Korrelationstabelle (KKT), Senckenbergiana lethaea 83 (1/2): $236-242$.

Korn, D., Ebbighausen, V., Bockwinkel, J. \& Klug, C. 2003a. The A-mode sutural ontogeny in prolecanitid ammonoids. - Palaeontology 46 (6): 1123-1132.

- 2003b. Palaeobiogeographic and evolutionary meaning of an early Late Tournaisian ammonoid fauna from the Tafilalt of Morocco. - Acta Palaeontologica Polonica 48 (1): $71-92$.

Korn, D. \& Weyer, D. 2003. High resolution stratigraphy of the Devonian-Carboniferous transitional beds in the Rhenish Mountains. - Mitteilungen aus dem Museum für Naturkunde Berlin, Geowissenschaftliche Reihe 6 (2003): $79-124$.

Lemosquet, Y., Conrad, J. \& Manger, W. M. 1985. Ammonoids. - In Weyant, M.: North Africa; in: Diaz, C. M. et al. (Eds.): The Carboniferous of the World; IUGS Publication 20: $367-372$.

Librovitch, L. S. 1940. Ammonoidea iz kamennougol'nykh otlozheniy Severnogo Kazakhstana [Carboniferous Ammonoids of North Kazakhstan]. - Paleontologiya SSSR 4 $(9 / 1): \mathrm{VI}+392 \mathrm{pp}$

- 1957. O nekotorykh novykh gruppakh goniatitov iz kamennougol'nykh otlozheniy SSSR. - Ezhegodnik Vsesoyuznogo Paleontologicheskogo Obshchestva 16: 246-272.

Meyendorff, A. 1939. Les couches de passage du Dévonien au Carbonifère dans le Gourara (Sahara occidental). Compte Rendus Hebdomadaires des Séances de l'Académie des Sciences [Paris] 209: 228-229.

Miller, A. K. \& Collinson, C. 1951. Lower Mississippian ammonoids of Missouri. - Journal of Paleontology 25: $454-487$.

Miller, A. K. \& Garner, H. F. 1955. Lower Mississippian cephalopods of Michigan. Part III. Ammonoids and summary. - Contributions of the Museum of Paleontology, University of Michigan 12: 113-173. 
Miller, S. A. \& Gurley, W. F. E. 1896. New species of Palaeozoic invertebrates from Illinois and other states. - Bulletin of the Illinois State Museum of Natural History 11: $1-50$.

Moore, R. C. 1928. Early Mississippian formations in Missouri. - Missouri Bureau of Geology and Mines, $2^{\text {nd }}$ series 21: $283 \mathrm{pp}$.

Ruan Yi-ping 1981. Devonian and earliest Carboniferous Ammonoids from Guangxi and Guizhou. - Memoires of Nanjing Institute of Geology and Paleontology, Academia Sinica 15: 1-152.

Sandberg, C. A., Ziegler, W., Leuteritz, K. \& Brill, S. M. 1978. Phylogeny, speciation, and zonation of Siphonodella (Conodonta, Upper Devonian and Lower Carboniferous). - Newsletters on Stratigraphy 7 (2): 102-120.

Schindewolf, O. H. 1922. Über eine Unterkarbonfauna aus Ostthüringen. - Senckenbergiana 4: 8-20.

- 1923. Beiträge zur Kenntnis des Paläozoikums in Oberfranken, Ostthüringen und dem Sächsischen Vogtlande. I. Stratigraphie und Ammoneenfauna des Oberdevons von Hof a. S. - Neues Jahrbuch für Mineralogie, Geologie und Paläontologie, Beilage-Band 49: 250-357, 393-509.
- 1937. Zur Stratigraphie und Paläontologie der Wocklumer Schichten (Oberdevon). - Abhandlungen der Preußischen Geologischen Landesanstalt, Neue Folge 178: 1-132.

Schmidt, H. 1922. Das Oberdevon-Culm-Gebiet von Warstein i. W. und Belecke. - Jahrbuch der Preußischen Geologischen Landesanstalt 41 (for 1920): 254-339.

- 1924. Zwei Cephalopodenfaunen an der Devon-Carbongrenze im Sauerland. - Jahrbuch der Preußischen Geologischen Landesanstalt 44 (for 1923): 98-171.

Smith, J. P. 1903. The Carboniferous ammonoids of America. - U.S. Geological Survey Monograph 42: 1-211.

Vöhringer, E. 1960. Die Goniatiten der unterkarbonischen Gattendorfia-Stufe im Hönnetal (Sauerland). - Fortschritte in der Geologie von Rheinland und Westfalen 3 (1): 107-196.

Weyer, D. 1965. Zur Ammonoideen-Fauna der GattendorfiaStufe von Dzikowiec (Ebersdorf) in Dolny Ślask (Niederschlesien). - Berichte der geologischen Gesellschaft in der Deutschen Demokratischen Republik für das Gesamtgebiet der geologischen Wissenschaften 10 (4): 443--464.

- 1977. Ammonoideen aus dem Untertournai von Schleiz (Ostthüringisches Schiefergebirge). - Zeitschrift für geologische Wissenschaften 5 (2): 167-185. 


\section{Appendix}

Conch dimensions and ratios of ammonoids from the Grès supérieurs de Kahla of the Gara el Kahla.

\begin{tabular}{|c|c|c|c|c|c|c|c|c|c|c|}
\hline & $\mathrm{dm}$ & ww & wh & uw & ah & WER & $\mathrm{ww} / \mathrm{dm}$ & ww/wh & $\mathrm{uw} / \mathrm{dm}$ & IZR \\
\hline \multicolumn{11}{|c|}{ Acutimitoceras algeriense $\mathrm{n} . \mathrm{sp}$. } \\
\hline MB.C.5463.1 & 19.01 & 7.97 & 10.93 & 0.41 & 5.96 & 2.12 & 0.42 & 0.73 & 0.02 & 0.45 \\
\hline MB.C.5463.2 & 16.6 & 8.45 & 9.06 & 0.32 & 5.19 & 2.12 & 0.51 & 0.93 & 0.02 & 0.43 \\
\hline MB.C.5463.3 & 16.08 & 8.33 & 9.73 & 0.34 & 5.15 & 2.16 & 0.52 & 0.86 & 0.02 & 0.47 \\
\hline MB.C. 5464.5 & 15.37 & 8.31 & 8.08 & 1.01 & 4.84 & 2.13 & 0.54 & 1.03 & 0.07 & 0.40 \\
\hline MB.C. 5464.15 & 14.34 & 7.58 & 7.87 & 0.69 & 4.44 & 2.10 & 0.53 & 0.96 & 0.05 & 0.44 \\
\hline MB.C. 5464.16 & 13.19 & 7.22 & 6.96 & 0.83 & 4.07 & 2.09 & 0.55 & 1.04 & 0.06 & 0.42 \\
\hline MB.C.5464.9 & 12.76 & 6.35 & 7.91 & 0.49 & 4.04 & 2.14 & 0.50 & 0.80 & 0.04 & 0.49 \\
\hline MB.C.5464.6 & 11.22 & 6.53 & 6.21 & 0.57 & 3.58 & 2.16 & 0.58 & 1.05 & 0.05 & 0.42 \\
\hline MB.C. 5464.7 & 8.92 & 5.41 & 4.88 & 0.6 & 2.82 & 2.14 & 0.61 & 1.11 & 0.07 & \\
\hline MB.C.5464.11 & 8.76 & 4.79 & 4.91 & 0.36 & 2.87 & 2.21 & 0.55 & 0.98 & 0.04 & \\
\hline MB.C. 5464.10 & 7.8 & 4.33 & 4.24 & 0.45 & 2.57 & 2.22 & 0.56 & 1.02 & 0.06 & \\
\hline MB.C. 5464.17 & 7.59 & 4.85 & 3.99 & 0.59 & 2.42 & 2.16 & 0.64 & 1.22 & 0.08 & \\
\hline \multirow[t]{6}{*}{ MB.C. 5464.1} & 13.63 & 7.78 & 7.93 & 0.40 & 4.30 & 2.14 & 0.57 & 0.98 & 0.03 & \\
\hline & 9.33 & 5.78 & 5.30 & 0.30 & 2.88 & 2.09 & 0.62 & 1.09 & 0.03 & \\
\hline & 6.45 & 4.53 & 3.72 & 0.46 & 2.07 & 2.16 & 0.70 & 1.22 & 0.07 & \\
\hline & 4.39 & 3.12 & 2.27 & 0.57 & 1.26 & 1.97 & 0.71 & 1.38 & 0.13 & \\
\hline & 3.12 & 2.48 & 1.54 & 0.53 & 0.85 & 1.89 & 0.79 & 1.61 & 0.17 & 0.45 \\
\hline & 2.27 & 2.02 & 1.05 & & 0.59 & 1.82 & 0.89 & 1.92 & & \\
\hline \multirow[t]{7}{*}{ MB.C. 5464.14} & 12.95 & 6.8 & 7.25 & 0.3 & 4.25 & 2.22 & 0.53 & 0.94 & 0.02 & 0.41 \\
\hline & 8.65 & 5.05 & 5.15 & 0.25 & 2.8 & 2.19 & 0.58 & 0.98 & 0.03 & \\
\hline & 5.9 & 3.95 & 3.35 & 0.28 & 1.9 & 2.18 & 0.67 & 1.18 & 0.05 & \\
\hline & 3.95 & 2.9 & 2.35 & 0.25 & 1.25 & 2.14 & 0.73 & 1.23 & 0.06 & 0.47 \\
\hline & 2.75 & 2.2 & 1.55 & 0.35 & 0.78 & 1.95 & 0.80 & 1.42 & 0.13 & \\
\hline & 1.9 & 1.55 & 1.02 & 0.38 & 0.52 & 1.90 & 0.82 & 1.52 & 0.20 & \\
\hline & 1.4 & 1.2 & 0.65 & 0.32 & 0.35 & 1.78 & 0.86 & 1.85 & 0.23 & \\
\hline
\end{tabular}

Acutimitoceras sinulobatum n. sp.

\begin{tabular}{|c|c|c|c|c|c|c|c|c|c|c|}
\hline MB.C.5465.1 & 12.39 & 8.31 & 6.56 & 1.16 & 2.77 & 1.66 & 0.67 & 1.27 & 0.09 & 0.58 \\
\hline MB.C.5465.14 & 11.62 & 7.26 & 6.16 & 0.89 & 2.78 & 1.73 & 0.62 & 1.18 & 0.08 & 0.55 \\
\hline MB.C.5465.4 & 10.87 & 7.3 & 4.93 & 0.98 & 2.46 & 1.67 & 0.67 & 1.48 & 0.09 & 0.50 \\
\hline MB.C.5465.13 & 10.47 & 6.1 & 4.53 & 1.67 & 2.5 & 1.73 & 0.58 & 1.35 & 0.16 & 0.45 \\
\hline MB.C.5465.5 & 10.31 & 7.54 & 5.12 & 1.29 & 2.29 & 1.65 & 0.73 & 1.47 & 0.13 & 0.55 \\
\hline MB.C. 5465.3 & 9.85 & 6.6 & 4.73 & 0.98 & 2.12 & 1.62 & 0.67 & 1.40 & 0.10 & 0.55 \\
\hline MB.C. 5465.6 & 8.35 & 6.41 & 4.46 & 1.54 & 1.67 & 1.56 & 0.77 & 1.44 & 0.18 & 0.63 \\
\hline МB.C. 5465.9 & 8.32 & 5.85 & 3.68 & 1.36 & 1.74 & 1.60 & 0.70 & 1.59 & 0.16 & 0.53 \\
\hline MB.C. 5465.7 & 8.08 & 6.24 & 3.25 & 1.62 & 1.69 & 1.60 & 0.77 & 1.92 & 0.20 & 0.48 \\
\hline MB.C.5465.8 & 6.9 & 5.34 & 3.31 & 1.33 & 1.51 & 1.64 & 0.77 & 1.61 & 0.19 & 0.54 \\
\hline \multirow[t]{6}{*}{ MB.C.5465.2 } & 11.18 & 8.51 & 5.35 & 1.71 & 2.29 & 1.58 & 0.76 & 1.59 & 0.15 & 0.57 \\
\hline & 8.88 & 7.24 & 4.12 & 1.39 & 1.65 & 1.51 & 0.81 & 1.76 & 0.16 & 0.60 \\
\hline & 7.24 & 5.99 & 3.38 & 1.29 & 1.37 & 1.52 & 0.83 & 1.78 & 0.18 & 0.59 \\
\hline & 5.87 & 4.75 & 2.57 & 1.19 & 1.25 & 1.62 & 0.81 & 1.85 & 0.20 & 0.51 \\
\hline & 4.61 & 4.05 & 2.11 & 1.09 & 1.06 & 1.69 & 0.88 & 1.92 & 0.24 & 0.49 \\
\hline & 3.58 & 3.17 & 1.47 & & 0.85 & 1.72 & 0.88 & 2.15 & & 0.42 \\
\hline \multirow[t]{7}{*}{ MB.C.5465.11 } & 11.51 & 7.29 & 6.02 & 0.93 & 2.55 & 1.65 & 0.63 & 1.21 & 0.08 & 0.58 \\
\hline & 8.96 & 6.28 & 4.56 & 0.84 & 1.93 & 1.62 & 0.70 & 1.38 & 0.09 & 0.58 \\
\hline & 7.03 & 5.23 & 3.56 & 0.86 & 1.62 & 1.69 & 0.74 & 1.47 & 0.12 & 0.55 \\
\hline & 5.57 & 4.46 & 2.61 & 1.00 & 1.18 & 1.61 & 0.80 & 1.71 & 0.18 & 0.55 \\
\hline & 4.40 & 3.54 & 1.96 & 0.97 & 0.91 & 1.59 & 0.81 & 1.81 & 0.22 & 0.54 \\
\hline & 3.48 & 2.87 & 1.47 & 0.79 & 0.79 & 1.67 & 0.83 & 1.95 & 0.23 & 0.47 \\
\hline & 2.69 & 2.42 & 1.21 & & 0.64 & 1.71 & 0.90 & 2.00 & & 0.48 \\
\hline \multirow[t]{7}{*}{ MB.C. 5465.12} & 7.45 & 5.15 & 3.74 & 0.93 & 1.68 & 1.67 & 0.69 & 1.38 & 0.13 & 0.55 \\
\hline & 5.76 & 4.56 & 2.78 & 1.02 & 1.31 & 1.67 & 0.79 & 1.64 & 0.18 & 0.53 \\
\hline & 4.46 & 3.56 & 1.97 & 0.98 & 1.07 & 1.73 & 0.80 & 1.81 & 0.22 & 0.46 \\
\hline & 3.39 & 3.03 & 1.51 & 0.79 & 0.76 & 1.66 & 0.89 & 2.01 & 0.23 & 0.50 \\
\hline & 2.63 & 2.12 & 1.09 & 0.71 & 0.63 & 1.72 & 0.80 & 1.94 & 0.27 & 0.42 \\
\hline & 2.01 & 1.81 & 0.84 & 0.56 & 0.46 & 1.69 & 0.90 & 2.16 & 0.28 & 0.45 \\
\hline & 1.54 & 1.34 & 0.61 & & & & 0.87 & 2.19 & & \\
\hline \multicolumn{11}{|c|}{ Acutimitoceras sp. A } \\
\hline MB.C.5466.3 & 15.93 & 8.34 & 8.12 & 1.12 & 3.9 & 1.75 & 0.52 & 1.03 & 0.07 & 0.52 \\
\hline MB.C.5466.5 & 11.07 & 6.82 & 5.79 & 0.78 & 2.9 & 1.84 & 0.62 & 1.18 & 0.07 & 0.50 \\
\hline MB.C.5466.6 & 9.91 & 6.08 & 5.27 & 1.15 & 2.74 & 1.91 & 0.61 & 1.15 & 0.12 & 0.48 \\
\hline
\end{tabular}




\begin{tabular}{lcccccccccc}
\hline & $\mathrm{dm}$ & ww & wh & uw & ah & wER & ww/dm & ww/wh & uw/dm & IZR \\
\hline MB.C.5466.1 & 10.83 & 6.81 & 5.90 & 0.53 & 2.97 & 1.90 & 0.63 & 1.15 & 0.05 & 0.50 \\
& 7.86 & 5.57 & 4.40 & 0.49 & 2.29 & 1.99 & 0.71 & 1.27 & 0.06 & 0.48 \\
& 5.57 & 4.37 & 2.97 & 0.57 & 1.49 & 1.86 & 0.78 & 1.47 & 0.10 & 0.50 \\
& 4.08 & 3.89 & 2.03 & 0.73 & 0.90 & 1.65 & 0.95 & 1.92 & 0.18 & 0.55 \\
& 3.18 & 2.76 & 1.32 & & 0.59 & 1.50 & 0.87 & 2.09 & & 0.56
\end{tabular}

Hasselbachia gourara n. sp.

$\begin{array}{llllllllllll}\text { MB.C.5467.1 } & 7.71 & 3.86 & 2.62 & 2.53 & 1.46 & 1.52 & 0.50 & 1.47 & 0.33 & 0.44 & 0.53 \\ \text { MB.C.5467.4 } & 7.55 & 3.93 & 3 & 2.37 & 1.42 & 1.52 & 0.52 & 1.31 & 0.31 & 0.53 \\ \text { MB.C.5467.3 } & 7.33 & 3.93 & 2.89 & 2.1 & 1.39 & 1.52 & 0.54 & 1.36 & 0.29 & 0.52 & \\ \text { MB.C.5467.5 } & 6.51 & 3.91 & 2.42 & 2.37 & 1.11 & 1.45 & 0.60 & 1.62 & 0.36 & 0.54 & 0.41 \\ \text { MB.C.5467.2 } & 4.70 & 3.25 & 1.41 & 2.24 & 0.83 & 1.47 & 0.69 & 2.31 & 0.48 & 0.41 \\ & 3.87 & 2.70 & 1.05 & 1.92 & 0.66 & 1.45 & 0.70 & 2.57 & 0.50 & 0.38 & 0.52 \\ & 3.21 & 2.32 & 0.90 & 1.61 & 0.52 & 1.42 & 0.72 & 2.59 & 0.50 & 0.42 & 0.31 \\ & 2.69 & 1.99 & 0.71 & 1.35 & 0.49 & 1.49 & 0.74 & 2.82 & 0.50 & 0.51 & 0.34 \\ & 2.21 & 1.70 & 0.64 & 1.12 & 0.42 & 1.53 & 0.77 & 2.67 & 0.51 & 0.38 & \end{array}$

Gattendorfia jacquelinae n. sp.

\begin{tabular}{|c|c|c|c|c|c|c|c|c|c|c|}
\hline MB.C.5462.1 & 15.32 & 11 & 4.3 & 6.55 & 3.08 & 1.57 & 0.72 & 2.56 & 0.43 & 0.28 \\
\hline MB.C. 5468.32 & 13.67 & 8.32 & 4.35 & 5.79 & 2.71 & 1.56 & 0.61 & 1.91 & 0.42 & 0.38 \\
\hline MB.C.5468.23 & 13.45 & 8.53 & 4.81 & 5.13 & 2.88 & 1.62 & 0.63 & 1.77 & 0.38 & 0.40 \\
\hline MB.C.5468.11 & 13.19 & 7.97 & 4.38 & 5.48 & 2.56 & 1.54 & 0.60 & 1.82 & 0.42 & 0.42 \\
\hline MB.C. 5462.2 & 12.65 & 8.45 & 4.2 & 4.96 & 2.72 & 1.62 & 0.67 & 2.01 & 0.39 & 0.35 \\
\hline MB.C.5468.9 & 11.55 & 7.7 & 3.61 & 4.82 & 2.47 & 1.62 & 0.67 & 2.13 & 0.42 & 0.32 \\
\hline MB.C.5468.53 & 11.05 & 6.69 & 3.84 & 4.53 & 2.64 & 1.73 & 0.61 & 1.74 & 0.41 & 0.31 \\
\hline MB.C.5468.54 & 10.93 & 5.69 & 3.58 & 4.26 & 2.43 & 1.65 & 0.52 & 1.59 & 0.39 & 0.32 \\
\hline MB.C. 5468.55 & 10.71 & 6 & 3.91 & 4.36 & 2.61 & 1.75 & 0.56 & 1.53 & 0.41 & 0.33 \\
\hline MB.C. 5468.40 & 10.52 & 6.81 & 3.79 & 4.53 & 2.27 & 1.63 & 0.65 & 1.80 & 0.43 & 0.40 \\
\hline МВ.С.5468.28 & 10.33 & 6.17 & 3.31 & 4.7 & 2.06 & 1.56 & 0.60 & 1.86 & 0.45 & 0.38 \\
\hline MB.C. 5468.35 & 10.31 & 5.88 & 3.2 & 4.61 & 2.02 & 1.55 & 0.57 & 1.84 & 0.45 & 0.37 \\
\hline MB.C. 5468.47 & 10.23 & 6.66 & 3.16 & 4.79 & 2.24 & 1.64 & 0.65 & 2.11 & 0.47 & 0.29 \\
\hline MB.C.5468.7 & 10.07 & 5.97 & 2.73 & 5.01 & 2.03 & 1.57 & 0.59 & 2.19 & 0.50 & 0.26 \\
\hline MB.C.5462.3 & 10.04 & 6.29 & 3.27 & 5 & 2.04 & 1.58 & 0.63 & 1.92 & 0.50 & 0.38 \\
\hline MB.C. 5468.15 & 9.75 & 4.32 & 2.83 & 4.61 & 1.77 & 1.49 & 0.44 & 1.53 & 0.47 & 0.37 \\
\hline MB.C.5468.41 & 9.74 & 5.93 & 2.57 & 4.73 & 1.99 & 1.58 & 0.61 & 2.31 & 0.49 & 0.23 \\
\hline MB.C. 5468.27 & 9.55 & 5.85 & 2.77 & 4.47 & 2 & 1.60 & 0.61 & 2.11 & 0.47 & 0.28 \\
\hline MB.C.5468.8 & 9.52 & 6.12 & 2.47 & 4.45 & 1.86 & 1.54 & 0.64 & 2.48 & 0.47 & 0.25 \\
\hline MB.C. 5468.21 & 9.34 & 5.71 & 2.62 & 4.37 & 2.16 & 1.69 & 0.61 & 2.18 & 0.47 & 0.18 \\
\hline MB.C.5468.14 & 8.97 & 5.22 & 2.41 & 4.83 & 1.72 & 1.53 & 0.58 & 2.17 & 0.54 & 0.29 \\
\hline MB.C.5468.45 & 8.94 & 4.82 & 2.57 & 4.76 & 1.66 & 1.51 & 0.54 & 1.88 & 0.53 & 0.35 \\
\hline MB.C. 5468.16 & 8.92 & 5.09 & 2.29 & 4.65 & 1.47 & 1.43 & 0.57 & 2.22 & 0.52 & 0.36 \\
\hline MB.C.5468.24 & 8.82 & 5.52 & 2.65 & 3.65 & 1.84 & 1.60 & 0.63 & 2.08 & 0.41 & 0.31 \\
\hline MB.C. 5468.25 & 8.8 & 5.26 & 2.38 & 4.41 & 1.83 & 1.59 & 0.60 & 2.21 & 0.50 & 0.23 \\
\hline MB.C. 5468.36 & 8.58 & 5.5 & 2.73 & 4.03 & 1.81 & 1.61 & 0.64 & 2.01 & 0.47 & 0.34 \\
\hline MB.C. 5468.42 & 8.43 & 5 & 2.26 & 3.95 & 1.74 & 1.59 & 0.59 & 2.21 & 0.47 & 0.23 \\
\hline MB.C. 5468.51 & 8.26 & 5.06 & 2.52 & 4.17 & 1.71 & 1.59 & 0.61 & 2.01 & 0.50 & 0.32 \\
\hline MB.C. 5468.49 & 8.18 & 5.17 & 2.32 & 3.79 & 1.64 & 1.56 & 0.63 & 2.23 & 0.46 & 0.29 \\
\hline MB.C.5468.44 & 8.15 & 4.62 & 2.71 & 3.92 & 1.45 & 1.48 & 0.57 & 1.70 & 0.48 & 0.46 \\
\hline MB.C.5468.37 & 8.01 & 4.9 & 2.3 & 3.92 & 1.6 & 1.56 & 0.61 & 2.13 & 0.49 & 0.30 \\
\hline MB.C. 5468.46 & 7.8 & 4.53 & 2.15 & 3.99 & 1.5 & 1.53 & 0.58 & 2.11 & 0.51 & 0.30 \\
\hline MB.C.5468.39 & 7.52 & 4.5 & 2.17 & 3.82 & 1.58 & 1.60 & 0.60 & 2.07 & 0.51 & 0.27 \\
\hline MB.C.5468.31 & 6.63 & 4.11 & 1.7 & 3.42 & 1.24 & 1.51 & 0.62 & 2.42 & 0.52 & 0.27 \\
\hline MB.C. 5468.52 & 4.94 & 2.71 & 1.59 & 2.5 & 0.96 & 1.54 & 0.55 & 1.70 & 0.51 & 0.40 \\
\hline \multirow[t]{9}{*}{ MB.C.5468.2 } & 14.44 & 9.86 & 4.97 & 5.54 & 2.87 & 1.56 & 0.68 & 1.98 & 0.38 & 0.42 \\
\hline & 11.57 & 7.24 & 3.93 & 4.59 & 2.22 & 1.53 & 0.63 & 1.84 & 0.40 & 0.43 \\
\hline & 9.35 & 6.04 & 3.06 & 3.92 & 1.92 & 1.59 & 0.65 & 1.98 & 0.42 & 0.37 \\
\hline & 7.43 & 4.22 & 2.37 & 3.24 & 1.51 & 1.58 & 0.57 & 1.78 & 0.44 & 0.36 \\
\hline & 5.91 & 3.49 & 1.82 & 2.72 & 1.24 & 1.60 & 0.59 & 1.92 & 0.46 & 0.32 \\
\hline & 4.67 & 2.43 & 1.37 & 2.24 & 0.92 & 1.55 & 0.52 & 1.77 & 0.48 & 0.33 \\
\hline & 3.76 & 2.25 & 1.06 & 1.79 & 0.70 & 1.51 & 0.60 & 2.12 & 0.48 & 0.34 \\
\hline & 3.05 & 1.66 & 0.90 & 1.39 & 0.66 & 1.63 & 0.54 & 1.84 & 0.45 & 0.27 \\
\hline & 2.39 & 1.56 & 0.76 & & 0.55 & 1.69 & 0.65 & 2.05 & & 0.27 \\
\hline
\end{tabular}




\begin{tabular}{lllllllllll}
\hline & $\mathrm{dm}$ & ww & wh & uw & ah & WER & ww/dm & ww/wh & uw/dm & IZR \\
\hline MB.C.5468.1 & 10.60 & 6.21 & 3.37 & 4.67 & 2.22 & 1.60 & 0.59 & 1.84 & 0.44 & 0.34 \\
& 8.38 & 4.85 & 2.56 & 3.96 & 1.76 & 1.60 & 0.58 & 1.89 & 0.47 & 0.31 \\
& 6.62 & 3.29 & 1.86 & 3.36 & 1.56 & 1.71 & 0.50 & 1.77 & 0.51 & 0.16 \\
& 5.06 & 2.74 & 1.41 & 2.67 & 1.08 & 1.61 & 0.54 & 1.95 & 0.53 & 0.23 \\
& 3.98 & 2.10 & 0.98 & 2.16 & 0.78 & 1.55 & 0.53 & 2.13 & 0.54 & 0.20 \\
& 3.20 & 1.81 & 0.84 & 1.72 & 0.65 & 1.57 & 0.57 & 2.16 & 0.54 & 0.23 \\
& 2.55 & 1.35 & 0.64 & 1.33 & 0.47 & 1.51 & 0.53 & 2.10 & 0.52 & 0.26 \\
& 2.08 & 1.27 & 0.51 & & & & 0.61 & 2.49 & &
\end{tabular}

Gattendorfia cf. crassa Schmidt. 1924

$\begin{array}{lcccccccccc}\text { MB.C.5469 } & 8.83 & 5.09 & 2.24 & 4.91 & 1.57 & 1.48 & 0.58 & 2.27 & 0.56 & 0.30 \\ & 7.26 & 3.68 & 1.69 & 4.22 & 1.25 & 1.46 & 0.51 & 2.18 & 0.58 & 0.26 \\ & 6.01 & 2.95 & 1.36 & 3.54 & 1.10 & 1.50 & 0.49 & 2.18 & 0.59 & 0.19 \\ & 4.91 & 2.34 & 1.12 & 2.90 & 0.86 & 1.47 & 0.48 & 2.09 & 0.59 & 0.23 \\ & 4.06 & 1.78 & 0.89 & 2.39 & 0.70 & 1.46 & 0.44 & 1.99 & 0.59 & 0.22 \\ & 3.36 & 1.51 & 0.78 & 1.98 & 0.60 & 1.49 & 0.45 & 1.95 & 0.59 & 0.22 \\ & 2.76 & 1.23 & 0.61 & 1.59 & 0.49 & 1.48 & 0.45 & 2.03 & 0.58 & 0.20 \\ & 2.27 & 1.10 & 0.56 & 1.22 & 0.47 & 1.58 & 0.49 & 1.96 & 0.54 & 0.17 \\ & 1.80 & 0.92 & 0.49 & 0.91 & 0.36 & 1.57 & 0.51 & 1.90 & 0.51 & 0.25 \\ \text { Kahlacanites meyendorffi n. sp. } & & & & & & & & & & \\ & 1.44 & 0.80 & 0.40 & 0.70 & 0.31 & 1.61 & 0.55 & 1.99 & 0.48 & 0.24 \\ \text { MB.C.5470.1 } & 9.45 & 2.97 & 3.09 & 4.26 & 2.96 & 2.12 & 0.31 & 0.96 & 0.45 & 0.04 \\ \text { Kahlacanites mariae } & \text { n. sp. } & & & & & & & & & \\ \text { MB.C.5471.1 } & 1.13 & 0.73 & 0.34 & 0.50 & 0.24 & 1.60 & 0.65 & 2.14 & 0.44 & 0.30 \\ \text { MB.C.5474 } & 18.16 & 5.63 & 6.92 & 6.09 & 4.81 & 1.85 & 0.31 & 0.81 & 0.34 & 0.30 \\ \text { MB.C.5471.3 } & 13.95 & 4.79 & 5.25 & 4.66 & 3.85 & 1.91 & 0.34 & 0.91 & 0.33 & 0.27 \\ \text { MB.C.5471.2 } & 11.81 & 4.07 & 5.36 & 3.41 & 3.14 & 1.86 & 0.34 & 0.76 & 0.29 & 0.41 \\ \text { Kahlacanites timimounensis n. sp. } & 10.35 & 4.05 & 3.91 & 3.11 & 2.77 & 1.86 & 0.39 & 1.04 & 0.30 & 0.29 \\ \text { MB.C.5472.2 } & 12.46 & 4.78 & 4.81 & 2.72 & 3.78 & 2.06 & 0.38 & 0.99 & 0.22 & 0.21 \\ \text { MB.C.5472.6 } & 10.47 & 3.76 & 5.08 & 1.81 & 3.29 & 2.13 & 0.36 & 0.74 & 0.17 & 0.35 \\ \text { MB.C.5472.5 } & 9.43 & 4.06 & 4.3 & 2.09 & 2.95 & 2.12 & 0.43 & 0.94 & 0.22 & 0.31 \\ \text { MB.C.5472.4 } & 6.91 & 3.19 & 3.27 & 1.53 & 2.16 & 2.12 & 0.46 & 0.98 & 0.22 & 0.34 \\ \text { MB.C.5472.1 } & 8.40 & 4.05 & 3.65 & 2.06 & 2.71 & 2.18 & 0.48 & 1.11 & 0.24 & 0.26 \\ & 5.69 & 3.07 & 2.70 & 1.23 & 1.90 & 2.25 & 0.54 & 1.14 & 0.22 & 0.30 \\ & 3.80 & 2.35 & 1.77 & 0.96 & 1.30 & 2.31 & 0.62 & 1.33 & 0.25 & 0.27 \\ & 2.50 & 1.58 & 1.07 & 0.69 & 0.78 & 2.11 & 0.63 & 1.48 & 0.28 & 0.27 \\ & 1.71 & 1.25 & 0.75 & & 0.48 & 1.94 & 0.73 & 1.68 & & 0.35\end{array}$

